\title{
Okul Öncesi Dönemde Anne-Çocuk Birlikte Hikâye Kitabı Okuma Davranışlarının İncelenmesi*
}

\author{
Müberra ARICI ${ }^{* *}$ \\ Aysel TÜFEKCI AKCAN ${ }^{* * *}$
}

\begin{abstract}
Öz: Araştırmanın amacı annelerin çocukları ile birlikte hikâye kitabı okuma davranışlarının incelenmesidir. Betimsel tarama modelinde desenlenen araştırmanın örneklemi çocukları anasınıflarına devam eden 436 anneden oluşmaktadır. Veriler ÇEBOE (Çocuk Ebeveyn Birlikte Okuma Etkinlikleri Ölçeği) ile toplanmıştır. Verilerin analizinde betimsel istatistiklere ek olarak, Student's t testi, Mann-Whitney U testi, Tek Yönlü Varyans Analizi (ANOVA) ve Kruskal-Wallis H testi uygulanmıştır. Yapılan analizler sonucunda annelerin birlikte etkileşimli okuma, birlikte okumaya yönelik görüşler ve okuryazarlığın önemi boyutlarını her zaman, okuryazarlık öğretimini ara sıra ve okuryazarlığa model olma boyutunu nadiren gerçekleştirdikleri ortaya çıkmıştır. Ayrıca, annelerin çocukları ile birlikte okuma davranışlarının, anne eğitim düzeyi ve sahip olunan çocuk sayısına göre; çocuklarına kitap okuma sıklıklarına, kitap okumaya ayırdıkları zamana, çocuklarıyla birlikte okuyabilecekleri kitap sayısına ve çocuklarına ilk kitabı alma yaşına göre anlamlı farklılık gösterdiği görülmüştür.
\end{abstract}

Anahtar Sözcükler: Birlikte Okuma, Etkileşimli Okuma, Okul Öncesi Dönem

\section{Investigation of Mother-Child Shared Storybook Reading Behaviors in Preschool Period}

\begin{abstract}
The aim of the research is to investigate mother-child shared storybook reading behaviors. The sample of the research, which is designed in the descriptive survey model, consists of 436 mothers whose children attend to kindergarten. The data were collected using ÇEBOE (Child-Parent Shared Reading Activities Scale). In addition to descriptive statistics, Student's t test, MannWhitney U test, One-Way Variance Analysis (ANOVA) and Kruskal-Wallis H test were used to analyze the data. As a result of the analyzes, it was found that mothers always participated in interactive reading, opinions of shared reading, and the importance of literacy; they occasionally participated in the dimension of literacy teaching, and rarely participated in the dimension of modeling literacy. In addition, it was found that mothers' shared reading behaviors were differed in accordance to mothers' level of education and the number of children they had; the frequency in which they read to their children, the time they spend in reading to their children, the number of books they could read to their children, and the age of the child when mothers bought them their first book.
\end{abstract}

Keywords: Shared Reading, Interactive Reading, Preschool Period

*** Milli Eğitim Bakanlığı, İstanbul, Türkiye. e-posta: mbr.arc.1990@gmail.com, ORCID: https://orcid.org/0000-0001-7825-3524

*** Gazi Üniversitesi, Okulöncesi Eğitimi Anabilim Dalı, Ankara, Türkiye. e-posta: tufekci@gazi.edu.tr, ORCID: https://orcid.org/0000-0001-7792-5624 
Eğitim alanında yapılan araştırmalar, kitap okumanın çocuğun gelişim alanları üzerindeki etkileri yoluyla akademik başarıda önemli bir rolü olduğunu göstermektedir. Ancak akademik başarı merkezli bakış açısı, kitapların insan yaşamındaki varoluşsal önemini görmemizi engelleyebilir. Kitaplar, varoluşu zaman ve mekânda sınırlı olan insana bu sınırları aşma olanağı sunan ender kaynaklardandır. Bir diğer ifadeyle, kitaplar aracılığıyla kişi zaman mekân sınırlarını aşarak insanlık ile temasa geçer, yaşadığı coğrafyanın ve içinde bulunduğu zamanın ötesindeki insanların duygu, düşünce ve deneyimleri aracıllğııla kendi dünyasını genişletme imkânı bulur. Böylece kişi sadece kendisini keşfetmekle kalmaz, aynı zamanda içinde yaşadığı dünya ile de daha otantik bir ilişki kurabilir. Bunun sonucunda kişi, içinde bulunduğu koşullar tarafından belirlenen edilgen bir varlık olmaktan çıkıp, kendi yaşam hikâyesinin aktif bir öznesi olma yönünde ilerleyebilir. $\mathrm{Bu}$ nedenle, erken yaşlardan başlayarak çocuklara kitap okuma sevgisi ve alışkanlığı kazandırmak son derece önemlidir.

Okul öncesi dönem, çocukların gelişimlerinin hızlı ve çevresel uyaranlara oldukça açık oldukları bir dönemdir. Bu dönemdeki çocuklarının gelişiminde etkili uyaranlardan biri de kuşkusuz çocuk edebiyatı ürünleridir. Çocuk edebiyatı, özellikle çocuklar için yazılmış, çocukların duygu ve düşünce dünyasına hitap eden, onları eğlendirirken bir yandan da eğiten, sanatsal niteliği yüksek edebi ürünler olarak tanımlanmıştır (Dursunoğlu, 2013; Sınar, 2006; Şimşek ve Yakar, 2014; Şirin, 2007; Tür ve Turla, 2005; Yalçın ve Aytaş, 2014).

Çocukların bilişsel, sosyal ve duygusal becerilerinin temellerinin atıldığı okul öncesi dönem, okuma sevgisi ve alışkanlığının kazandırılması açısından da kritik bir önem taşımaktadır. İçinde bulundukları çevreye yoğun merak duyan çocuklar, yazılı materyallere karşı da doğal bir ilgi gösterirler. Sokakta gördükleri tabela yazıları, kardeşlerinin ders kitapları, eve giren gazete ve dergiler gibi yazılı materyaller çocukların dikkatini ve ilgisini çeker. Henüz okuma becerisinin kazanılmadığı çok erken yaşlarda bile çocuklar, yazılı materyalleri inceleyerek bunları anlamlandırmaya çalışılar. Çocuklardaki bu doğal ilgi, uygun yetişkin desteği sağlandığında okuma sevgisi ve alışkanlığının temellerini oluşturacak şekilde geliştirilebilir (Çakmak Güleç ve Geçgel, 2006; Döl, 1999). Bu nedenle çocuklardaki doğal ilginin okuma sevgisi ve alışkanlığına dönüşmesini sağlamada ve bu suretle küçük çocukların okuryazarlığa yönelik bilgi, beceri ve tutumlarını ifade eden (Ergül, Akoğlu, Sarıca, Tufan ve Karaman, 2015; Tercanlı Metin ve Gökçay, 2014; Whitehurst ve Lonigan, 1998) erken okuryazarlık (emergent literacy) becerilerini desteklemede ebeveyn ve öğretmenlere önemli bir rol düşmektedir (Akyol, 2012; Gönen ve Arı, 1989; Gönen, Durmuşoğlu ve Severcan, 2009; Sever, 2017). Çocukların erken yaşlardan itibaren gelişim seviyelerine uygun nitelikli çocuk edebiyatı ürünleriyle karşılaşmalarını sağlamak (Aytaş, 2003; Sever, 2017; Temizyürek, 2003) ve çocuklarla birlikte okuma faaliyetinde bulunmak (Çakmak Güleç ve Geçgel, 2006; Işıkoğlu Erdoğan, 2016; Morrow ve Gambrell, 2005; Tipton, 2014; Veziroğlu, 2009; Whitehurst ve Lonigan, 1998; Yurtseven, 2011) bir yandan onların okuma sevgisi ve alışkanlığı kazanmalarında, diğer yandan da erken okuryazarlık becerilerinin gelişmesine katkıda bulunur.

Araştırmalar erken yaşlarda nitelikli çocuk edebiyatı ürünlerinin, çocuklarda alıcı ve ifade edici dil becerileri ile erken okuryazarlık becerilerinin gelişimine katkıda bulunduğunu (Baker, Scher ve Mackler, 1997; Bus ve van Ijzendoorn, 1995; Bus, van Ijzendoorn ve Pellegrini, 1995; Gönen ve Arı, 1989; Karakuş, 2006; Kurt, 2008; Er, 2016; Yavuzer, 1995) ve çocukların hayata bakış açılarını çeşitlendirmenin yanı sıra onların sanatsal, sosyal ve duygusal duyarlıklarını desteklediğini (Akyol, 2012; Er, 2016; Gibbs ve Early, 1994; Kolaç, Demir ve Karadağ, 2012; Kraayenoord ve Paris, 1996; Şirin, 2000; Veziroğlu, 2009; Yalçın ve Aytaş, 2014; Yurtseven, 2011) göstermektedir.

İlgili alanyazın okulöncesi dönemdeki dil ve erken okuryazarlık becerilerinin, ilerleyen yıllardaki okuma ve akademik başarının önemli bir yordayıcısı olduğunu göstermektedir (Bracken ve Fischel, 2008; Kotaman, 2007, 2009; Revelle ve Bowman, 2017; Saracho, 2017; Shahaeian ve diğerleri, 2018; Whitehurst ve Lonigan, 1998; Wu ve Honig, 2010). Alanyazında ortak okuma (joint reading), etkileşimli okuma (interactive reading) ya da diyalojik okuma (diyalogical reading) olarak da geçen birlikte okuma (shared reading), ev erken okuryazarlık ortamının (home literacy environment) erken okuryazarlık ve dil gelişimini etkileyen önemli unsurlarından biridir. 
Birlikte okuma, bir yetişkinin çocuğa kitap okumasını ve bu süreçte çocuk ile yetişkin arasındaki etkileşimi ifade eder (Gonzalez, Taylor, Davis ve Kim, 2013; Hindman, Skibbe ve Foster, 2014; Işıkoğlu Erdoğan, 2016). Yetişkinin onu dinleyen çocuğa kitap okumasını ifade eden geleneksel okumadan farklı olarak birlikte okuma kavramı, yetişkin ile çocuk arasındaki etkileşimi ve çocuğun hikâye okuma sürecinde etkin katılımını vurgular (Dixon-Krauss, Januszka ve Chae, 2010; Hindman, Connor, Jewkes ve Morrison, 2008). Birlikte okuma etkinliği bir yandan çocuk ile yetişkinin keyifli vakit geçirmesini sağlayarak aralarındaki bağı kuvvetlendirirken, diğer yandan da çocuğun kitaptaki yazıların eğlenceli masallara, öykülere dönüştügünü görmesini sağlayarak onda okumaya karşı ilgi ve sevgi uyandırır (Çer, 2016; Deretarla Gül, 2015; Kıbrıs, 2000; Oktay, 2000; Sever, 2017).

Yurtdışında birlikte okumaya yönelik pek çok araştırma olmasına karşın (Kim ve Anderson, 2008; Tercanlı Metin ve Gökçay, 2014), birlikte okuma ülkemizde görece yeni bir yöntem olduğundan (Kotaman, 2007), son yıllarda ve sınırlı sayıda araştırmaya konu olmuştur (Ergül ve diğerleri, 2015; Tercanlı Metin ve Gökçay, 2014). Yurtiçi ve yurtdışında yapılan araştırmalar, birlikte okumanın çocukların okuma ilgisi ve alışkanlığı kazanmalarında (Bracken ve Fischel, 2008; Demir-Lira, Applebaum, Goldin-Meadow ve Levine, 2018; Duursma, 2014; Kotaman, 2008; Öztürk, Hill ve Yates, 2016; Shahaeian ve diğerleri, 2018; Vandermaas-Peeler, Sassine, Price ve Brilhart, 2011), erken okuryazarlık ve dil gelişiminde (Aram ve Shapira, 2012; Bıçakçı, Er ve Aral, 2018; Bracken ve Fischel, 2008; Demir-Lira ve diğerleri, 2018; Duursma, 2014; Ergül ve diğerleri, 2015; Kotaman, 2008, 2009; Levy, Hall ve Preece, 2018; Lin, Stephanie ve Sabrina, 2015; Lyytinen, Laakso ve Poikkeus, 1998; Raikes ve diğerleri, 2006; Saracho, 2017; Shahaeian ve diğerleri, 2018; Vandermaas-Peeler ve diğerleri, 2011; Whitehurst ve diğerleri, 1988) empati gelişiminde (Aram ve Shapira, 2012; Tercanlı Metin ve Gökçay, 2014) ve bilişsel gelişimde (Hutton ve diğerleri, 2017a, 2017b; Shahaeian ve diğerleri, 2018) önemli rol oynadığını göstermektedir.

Son zamanlarda yürütülen çalışmalar, birlikte okumanın çocuklar üzerindeki bu etkilerinin, birlikte okumanın sıklığına ek olarak ve hatta ondan daha çok, niteliğine bağlı olduğunu göstermektedir (Duursma, 2016; Marjanovič-Umek, Hacin ve Fekonja, 2017; Raikes ve diğerleri, 2006; Saracho, 2017; Vandermaas-Peeler ve diğerleri, 2011; Wu ve Honig, 2010). Zira birlikte okuma esnasında ebeveyn ile çocuk arasındaki ilişki güçlenmekte, ebeveyn çocuğa kitabın nasıl tutulacağı, yazılı metnin yukarıdan aşağı ve soldan sağa okunacağı, kitabın sayfalarının önden arkaya çevrileceği gibi temel okuryazarlık becerileri konusunda model teşkil etmekte (Baroody ve Diamond, 2010; Duursma, 2016), okuma sürecine çocuğun aktif katılımını sağlamakta (Baroody ve Diamond, 2010) ve çocukla gündelik etkileşimde kullandığı dilden daha üst düzeyde bir dil kullanmaktadır (Baroody ve Diamond, 2010; Demir-Lira ve diğerleri, 2018; Duursma, 2014; Gilkerson, Richards ve Topping, 2015; Krcmar ve Cingel, 2014; Lyytinen ve diğerleri, 1998; Marjanovič-Umek ve diğerleri, 2017; Saracho, 2017; Shahaeian ve diğerleri, 2018).

Ne var ki ebeveyn-çocuk birlikte okuma faaliyetlerinin sıklığını ve niteliği etkileyen pek çok unsur bulunmaktadır. Aile ve ebeveyn özelliklerinden kaynaklanan unsurların başında aile sosyoekonomik düzeyi (Duursma, 2014, 2016; Raikes ve diğerleri, 2006; Tercanlı Metin ve Gökçay, 2014), ebeveynin eğitim düzeyi (Bracken ve Fischel, 2008; Duursma, 2014; Lyytinen ve diğerleri, 1998; Raikes ve diğerleri, 2006; Tercanlı Metin ve Gökçay, 2014; Wu ve Honig, 2010), ebeveyn cinsiyeti (Duursma, 2016; Işıkoğlu Erdoğan, 2016; Levy ve diğerleri, 2018; Tercanlı Metin ve Gökçay, 2014; Vandermaas-Peeler ve diğerleri, 2011) yer alır. Ayrıca, ebeveynin okumaya yönelik tutumu (Levy ve diğerleri, 2018), birlikte okumaya yönelik ilgi ve inançları (Bojczyk, Davis ve Rana, 2016; Bracken ve Fischel, 2008; Duursma, 2014; Husain, Choo ve Singh, 2011; Levy ve diğerleri, 2018; Raikes ve diğerleri, 2006; Saracho, 2017; Tercanlı Metin ve Gökçay, 2014; Wu ve Honig, 2010), okuma ve birlikte okuma özyeterlik algıları (Lin ve diğerleri, 2015; Kotaman, 2009) ve çocuğun hazırbulunuşluğuna dair inançları (Bojczyk ve diğerleri, 2016; Öztürk ve diğerleri, 2016; Wu ve Honig, 2010) da birlikte okuma faaliyetlerinin sıklık ve niteliğini etkileyen değişkenlerdendir.

Birlikte okuma faaliyetlerinin sıklık ve niteliğini etkileyen çocuk özellikleri arasında ise çocuğun yaşı (Duursma, 2014; Gilkerson ve diğerleri, 2015; Marjanovič-Umek ve diğerleri, 2017; Tercanlı Metin ve Gökçay, 2014; Whitehurst ve diğerleri, 1988; Wu ve Honig, 2010), cinsiyeti (Gilkerson ve diğerleri, 2015; Raikes ve diğerleri, 2006; Tercanlı Metin ve Gökçay, 2014; Vandermaas-Peeler ve diğerleri, 2011), doğum sırası (Raikes ve diğerleri, 2006; Tercanlı Metin ve Gökçay, 2014), dil ve bilişsel gelişim düzeyi ile okumaya ilgisi (Bracken 
ve Fischel, 2008; Hutton ve diğerleri, 2017a, 2017b; Kotaman, 2008; Krcmar ve Cingel, 2014; Lyytinen ve diğerleri, 1998; Marjanovič-Umek ve diğerleri, 2017; Raikes ve diğerleri, 2006; Saracho, 2017), kitaplara erişimi (Raikes ve diğerleri, 2006) ve okunan metnin türü ile metnin basılı ya da dijital formatta oluşu (Kim ve Anderson, 2008; Krcmar ve Cingel, 2014; Revelle ve Bowman, 2017; Saracho, 2017) yer almaktadır.

Birlikte okuma etkinliğinin çocukların başta dil becerileri olmak üzere bilişsel, duygusal ve sosyal gelişimine olan katkılarından dolayı ebeveynlerin çocuğun doğumundan itibaren birlikte okuma faaliyetlerinde bulunmaları önerilmekte ve bu doğrultuda aile eğitim programları uygulanmaktadır (Hutton, 2017b; Işıkoğlu Erdoğan, 2016; Kotaman, 2009; Tercanlı Metin ve Gökçay, 2014; Whitehurst ve Lonigan, 1998). Birlikte okumaya yönelik aile eğitim programlarının, ev okuryazarlık ortamı ve birlikte okuma faaliyetlerinin sıklık ve niteliğinde olumlu etkilere yol açtığı görülmüştür (Bıçakçı, Er ve Aral, 2017; Duursma, 2014, 2016; Levin ve Aram, 2012; Tercanlı Metin ve Gökçay, 2014; Whitehurst ve diğerleri, 1988; Whitehurst ve Lonigan, 1998). Bu tür programlara katıldıktan sonra ebeveynlerin, okul öncesi dönemde olan çocukları ile daha sık birlikte okuma yaptıkları, yapılan birlikte okuma faaliyetlerinin çocukların dil ve erken okuryazarlık becerilerinin gelişimine katkıda bulunduğu, çocukların ilerleyen yıllardaki akademik başarılarını arttırdığı ve bunun özellikle de düşük sosyoekonomik düzeydeki ailelerin çocukları için söz konusu olduğu görülmektedir (Raikes ve diğerleri, 2006; Shahaeian ve diğerleri, 2018).

Çocukların yaşam boyu gelişiminde bu derece önemli rolü olan birlikte okuma faaliyetlerinin ülkemizde de yaygınlaştırılması ve anne baba eğitim programları kapsamında değerlendirilebilmesi açısından öncelikle mevcut durumun tespiti önem taşımaktadır. Ne var ki ülkemizde bu alanda oldukça sınırlı sayıda araştırma yürütülmüştür. Bu ihtiyaçtan hareketle araştırmanın amacı, annelerin evde okul öncesi dönemde olan çocuklarıyla birlikte hikâye kitabı okuma etkinliklerini incelemektir. Bu amaç doğrultusunda şu sorulara yanıt aranmıştır:

1. Araştırmaya katılan annelerin evde çocuklarıyla birlikte hikâye okuma davranışları ve okuma alışkanlıkları nasıldır?

2. Araştırmaya katılan annelerin çocuklarıyla birlikte hikâye kitabı okuma davranışları, annelerin çocuklarına kitap okuma sıklığına, kitap okumaya ayrılan zamana, evde çocuklarına okuyabilecekleri kitap sayısına ve çocuklarına ilk kitabı alma yaşına göre değişmekte midir?

3. Araştırmaya katılan annelerin çocuklarıyla birlikte hikâye kitabı okuma davranışları, aylık gelir düzeyi; anne yaşı ve eğitim düzeyi, sahip olunan çocuk sayısı; çocuğun yaşı ve cinsiyetine göre değişmekte midir?

\section{Yöntem}

\section{Araştırmanın Modeli}

Araştırmada annelerin evde çocuklarıyla birlikte hikâye kitabı okuma davranışlarının incelenmesi amaçlandığından nicel araştırma desenlerinden betimsel tarama yöntemi kullanılmıştır. Betimsel araştırmalar, verilen bir durumu olabildiğince tam ve dikkatli bir şekilde tanımlamaktadır (Büyüköztürk, Kılıç Çakmak, Akgün, Karadeniz ve Demirel, 2014).

\section{Evren ve Örneklem}

Araştırmanın evrenini İstanbul ili Pendik ilçesinde MEB'e bağlı ilköğretim ve ortaokul bünyelerindeki anasınıflarında eğitim gören 4-5 yaş grubu çocukların anneleri oluşturmaktadır. Araştırmanın örneklemini belirlemek üzere her bir alt evrenden o alt evrenin bütün içindeki oranını yansıtacak şekilde örneklem seçilmesini gerektiren küme örnekleme tekniği kullanılmıştır. Bu doğrultuda İstanbul Pendik'te, bünyesinde anasınıfı bulunan 46 ilkokul ve 53 ortaokul olmak üzere toplam 99 okulun listesi çıkarılmış, listeden yansız olarak 4 'ü alt, 3'ü orta ve 4'ü üst sosyoekonomik düzeydeki yerleşim yerlerinde bulunan 11 okul örnekleme dâhil edilmiştir. Gerekli yasal izinler alındıktan sonra bu okullarda çocukları öğrenim gören 1000 anneye öğretmenler aracılı̆̆ı ile veri toplama araçları ulaştırılmış ve bir hafta sonrasında yine öğretmenler aracılığı ile teslim alınmıştır. Araştırmada 600 anneye ulaşılması hedeflenmiş, ancak 436 anneden geçerli veri toplama aracı geri dönüşü sağlanmıştır. Çalışmaya katılan annelerin demografik özellikleri incelendiğinde annelerin \%64'ünün 30-39 yaşlarında, \%68,9'unun lise ve üstü eğitim düzeyinde, \%65,4'ünün ev hanımı olduğu, 
\%77,3'ünün 2 ve üzeri sayıda çocuk sahibi oldukları ve \%55'inin aylık gelir düzeyinin 3001 TL ve üzeri olduğu görülmüştür.

\section{Veri Toplama Araçları}

Çocuk-Ebeveyn Birlikte Okuma Etkinlikleri Ölçeği (ÇEBOE). Araştırmada, annelerin evde çocuklarıyla birlikte hikâye kitabı okuma davranışlarını değerlendirmek için Işıkoğlu Erdoğan (2016) tarafından geliştirilen Çocuk-Ebeveyn Birlikte Okuma Etkinlikleri Ölçeği (ÇEBOE) kullanılmıştır. Ölçek iki bölümden oluşmaktadır. İlk bölümde, ebeveyn ve çocuk demografik bilgilerine yönelik 6 soru ve evde okuma alışkanlıklarına yönelik 7 soru yer almaktadır. İkinci bölümde, çocuk-ebeveyn birlikte okuma davranışlarını ölçmeye yönelik $4^{\prime}$ lü Likert tipinde (1: hiçbir zaman; 2: nadiren; 3 ara sıra ve 4: her zaman) 31 madde yer almaktadır. İkinci bölüm, Birlikte Etkileşimli Okuma (9 madde, $\alpha$.80), Birlikte Okumaya Yönelik Görüşler (8 Madde, $\alpha .79$ ), Okuryazarlığa Model Olma (6 madde, $\alpha$.76), Okuryazarlığın Önemi (4 madde, $\alpha$.70) ve Okuryazarlık Öğretimi (4 madde, $\alpha$.70) olmak üzere beş alt boyuttan oluşmaktadır (Işıkoğlu Erdoğan, 2016).

Araştırma kapsamında ölçeğin güvenirlik katsayıları yeniden hesaplanmış ve Cronbach alpha değerlerinin "Birlikte Etkileşimli Okuma” boyutu için .78, "Birlikte Okumaya Yönelik Görüşler" boyutu için .68 , “Okuryazarlığa Model Olma” boyutu için .68, “Okuryazarlığın Önemi” boyutu için .61 ve “Okuryazarlık öğretimi" boyutu için .64 olduğu görülmüştür.

\section{Verilerin Analizi}

Ölçeğin birinci bölümünde yer alan bağımsız değişkenler ile anne-çocuk birlikte okuma alışkanlıklarına yönelik verilerin yüzde ve frekans değerleri hesaplanmıştır. Ölçeğin ikinci bölümünde yer alan anne-çocuk birlikte okuma davranışına yönelik verilerin analizinde birlikte okuma davranış seviyelerini belirlemek amacıyla verilerin ortalama ve standart sapma değerlerine bakılmıştır. Anne-çocuk birlikte okuma davranışlarının, birlikte okuma alışkanlıkları ve bağımsız değişkenlere göre farklılık gösterip göstermediğini belirlemek için, öncelikle verilerin parametrik test koşullarını sağlanıp sağlamadığına bakılmıştır. İki grubun karşılaştırılması amacıyla parametrik test koşullarının sağlandığı değişkenler için Student's $t$ testi, parametrik test koşullarının sağlanmadığı durumlarda ise Mann-Whitney U testi kullanılmıştır. Üç ve daha fazla grubun karşılaştırılmasında parametrik test koşullarının sağlandığı durumlarda Tek Yönlü Varyans Analizi (ANOVA), parametrik test koşullarının sağlanmadığı durumlarda ise Kruskal-Wallis H testi uygulanmıştır. Bu analizler için SPSS (Statistical Package for Social Sciences) version 15 kullanılmıştır.

\section{Bulgular}

\section{Annelerin Evde Çocuklarıyla Birlikte Hikâye Okuma Alışkanlıkları ve Okuma Davranışlarına İlişkin} Bulgular

Çalışmaya katılan annelerin evde çocuklarına kitap okuma alışkanlıklarına ilişkin yüzde ve frekans dağılımları Tablo 1'de sunulmuştur.

Tablo I.

Annelerin Evde Çocuklarına Kitap Okuma Alışkanlıklarına İlişkin Yüzde ve Frekans Dağılımları

\begin{tabular}{llc}
\hline Kitap Okuma Alışkanlıkları & $\mathrm{f}$ & $\%$ \\
\hline Kitap Okuma Sıklı̆̆ı & & 10,3 \\
\hline Neredeyse hiç & 45 & 27,8 \\
Ayda 1-2 kez & 121 & 37,2 \\
Haftada 1-2 kez & 162 & 24,8 \\
Hemen hemen her gün & 108 & \\
\hline Kitap Okumaya Ayrılan Süre & & 5,0 \\
\hline dakika & 22 & 23,4 \\
1-10 dakika & 102 & \\
\hline
\end{tabular}




\begin{tabular}{lll}
\hline 11-20 dakika & 205 & 47,0 \\
20 dakikadan fazla & 107 & 24,5 \\
\hline Çocuğa Evde Okunabilecek Kitap Sayısı & & 6,2 \\
\hline $0-2$ adet & 27 & 17,7 \\
$3-5$ adet & 77 & 25,7 \\
6 -10 adet & 112 & 50,5 \\
11 -20 adet & 220 & 8,3 \\
\hline Çocuğa İlk Kitabın Alındığı Yaş & & 23,4 \\
\hline Doğduğunda & 36 & 19,3 \\
1 yaşından sonra & 102 & 23,2 \\
2 yaşından sonra & 84 & 11,7 \\
3 yaşından sonra & 101 & 14,2 \\
4 yaşından sonra & 51 & 62 \\
5 yaşından sonra & & \\
\hline
\end{tabular}

Tablo 1'de görüldüğü gibi, araştırmaya katılan annelerin \%37,2'sinin çocuklarına haftada 1-2 kez, \%24,8'inin hemen her gün kitap okudukları, \%10,3'ünün ise neredeyse hiç kitap okumadıkları görülmüştür. Çalı̧̧maya katılan annelerin \%47'sinin birlikte kitap okumaya 11-20 dakika süre ayırdıkları görülmektedir. Ayrıca annelerin \%50,5'inin çocuklarına okumak için 11-20 adet kitaba sahip oldukları ve çoğunluğunun çocuklarına ilk kitaplarını 1 yaşından $(\% 23,4)$ ve 3 yaşından $(\% 23,2)$ sonra aldıkları tespit edilmiştir.

Annelerin ÇEBOE'nin alt boyutlarından aldıkları puanların tanımlayıcı istatistikleri Tablo 2' de verilmiştir. Tablo II.

Annelerin ÇEBOE'nin Alt Boyutlarından Aldıkları Puanları Tanımlayııı İstatistikleri

\begin{tabular}{llcccc}
\hline ÇEBOE alt boyutları & Ortalama & $\begin{array}{l}\text { Etkinliğin gerçekleştirilme } \\
\text { sıklı̆̆ı }\end{array}$ & SS & Min. & Max. \\
\hline Birlikte Etkileşimli Okuma & 3,43 & Her zaman & 0,47 & 1,00 & 4,00 \\
Birlikte Okumaya Yönelik Görüşler & 3,36 & Her zaman & 0,45 & 1,75 & 4,00 \\
Okuryazarlığa Model Olma & 2,45 & Nadiren & 0,62 & 1,00 & 4,00 \\
Okuryazarlı̆̆ı̆ Önemi & 3,90 & Her zaman & 0,22 & 3,00 & 4,00 \\
Okuryazarlık Öğretimi & 2,58 & Ara sıra & 0,75 & 1,00 & 4,00 \\
\hline
\end{tabular}

Tablo 2' de görüldüğü üzere, annelerin ÇEBOE ölçeğinden en yüksek ortalamayı sırasıyla 'Okuryazarlı̆̆ın Önemi $(3,90)$, ' Birlikte Etkileşimli Okuma $(3,43)$ ' ve ' Birlikte Okumaya Yönelik Görüşler $(3,36)$ ' boyutlarından aldıkları ve $4^{\prime}$ lü derecelendirme sistemine göre bu alandaki etkinlikleri her zaman gerçekleştirdikleri görülmüştür. Çalışmaya katılan annelerin en düşük ortalamayı ise 'Okuryazarlığa Model Olma $(2,45)^{\prime}$ ve 'Okuryazarlık Öğretimi $(2,58)$ ' boyutlarından aldıkları ve bu alandaki etkinlikleri sırasıyla nadiren ve ara sıra gerçekleştirdikleri tespit edilmiştir.

\section{Annelerin Çocuklarıyla Birlikte Hikâye Okuma Davranışlarının Okuma Alışkanlıklarına Göre Değişip Değişmediğine İlişkin Bulgular}

Annelerin çocuklarına kitap okuma sıklıklarına göre ÇEBOE alt boyutlarından aldıkları puanlar Tablo 3'te sunulmuştur.

Tablo III.

Annelerin Çocuklarına Kitap Okuma Sıklı̆̆ına Göre ÇEBOE Alt Boyutlarından Alınan Puanlar

\begin{tabular}{lllllll}
\hline ÇEBOE alt boyutları & Kitap okuma sıklığı & Sayı & Ortalama & SS & Test istatistiği & p-değeri \\
\hline \multirow{3}{*}{$\begin{array}{l}\text { Birlikte etkileşimli } \\
\text { okuma }\end{array}$} & Neredeyse hiç & 45 & 3,20 & 0,75 & & \\
& Ayda 1-2 kez & 121 & 3,36 & 0,47 & & 0,006 \\
& Haftada 1-2 kez & 162 & 3,46 & 0,43 & $X^{2}=12,607$ & Fark: \\
& Hemen hemen her gün & 108 & 3,57 & 0,32 & & $1,2-3,4$ \\
\hline
\end{tabular}




\begin{tabular}{|c|c|c|c|c|c|c|}
\hline \multirow{4}{*}{$\begin{array}{l}\text { Birlikte okumaya } \\
\text { yönelik görüşler }\end{array}$} & Neredeyse hiç & 45 & 2,83 & 0,50 & \multirow{4}{*}{$X^{2}=120,76$} & \multirow{4}{*}{$\begin{array}{l}<0,001 \\
\text { Fark: } \\
1-2-3-4\end{array}$} \\
\hline & Ayda 1-2 kez & 121 & 3,19 & 0,40 & & \\
\hline & Haftada 1-2 kez & 162 & 3,43 & 0,38 & & \\
\hline & Hemen hemen her gün & 108 & 3,67 & 0,29 & & \\
\hline \multirow{4}{*}{$\begin{array}{l}\text { Okuryazarlığa model } \\
\text { olma }\end{array}$} & Neredeyse hiç & 45 & 2,02 & 0,57 & \multirow{4}{*}{$\mathrm{F}=20,251$} & \multirow{4}{*}{$\begin{array}{l}0,001 \\
\text { Fark: } \\
1,2-3,4\end{array}$} \\
\hline & Ayda 1-2 kez & 121 & 2,26 & 0,59 & & \\
\hline & Haftada 1-2 kez & 162 & 2,57 & 0,60 & & \\
\hline & Hemen hemen her gün & 108 & 2,67 & 0,55 & & \\
\hline \multirow{4}{*}{ Okuryazarlığın önemi } & Neredeyse hiç & 45 & 3,88 & 0,29 & \multirow{4}{*}{$X^{2}=0,204$} & \multirow{4}{*}{0,977} \\
\hline & Ayda 1-2 kez & 121 & 3,90 & 0,20 & & \\
\hline & Haftada 1-2 kez & 162 & 3,90 & 0,23 & & \\
\hline & Hemen hemen her gün & 108 & 3,91 & 0,21 & & \\
\hline \multirow{4}{*}{ Okuryazarlık öğretimi } & Neredeyse hiç & 45 & 2,39 & 0,68 & \multirow{4}{*}{$X^{2}=3,246$} & \multirow{4}{*}{0,355} \\
\hline & Ayda 1-2 kez & 121 & 2,63 & 0,66 & & \\
\hline & Haftada 1-2 kez & 162 & 2,59 & 0,78 & & \\
\hline & Hemen hemen her gün & 108 & 2,57 & 0,82 & & \\
\hline
\end{tabular}

$\mathrm{X}^{2}$ : Kruskal-Wallis Ki-Kare değeri; $F$ : Tek yönlü varyans analizi (ANOVA) F değeri

Tablo 3'te görüldüğü gibi, annelerin çocuklarına kitap okuma sıklıklarına göre ‘Okuryazarlığın Önemi' ve 'Okuryazarlık Öğretimi' boyutlarından alınan puanlar arasında istatistiksel açıdan anlamlı bir fark bulunmamıştır ( $p>0,05)$. 'Birlikte Etkileşimli Okuma' ve 'Okuryazarlığa Model Olma' boyutlarında neredeyse hiç kitap okumayan ve ayda 1-2 kez kitap okuyan annelerin puanlarının, haftada 1-2 kez ve hemen hemen her gün kitap okuyan annelerin puanlarına göre istatistiksel olarak anlamlı derecede düşük olduğu görülmüştür $(p<0,05)$. 'Birlikte Okumaya Yönelik Görüşler' boyutunda da neredeyse hiç kitap okumayan annelerin, ayda 1-2 kez, haftada 1-2 kez ve hemen hemen her gün kitap okuyan annelerin puanları arasında anlamlı farklılık olduğu ve farkın okuma sıklığı yüksek olan anneler lehine olduğu görülmüştür $(p<0,05)$.

Annelerin çocuklarına kitap okumaya ayırdıkları zamana göre ÇEBOE alt boyutlarından aldıkları puanlar Tablo 4'de sunulmuştur.

Tablo IV.

Annelerin Çocuklarına Kitap Okumaya Ayırdıkları Zamana Göre ÇEBOE Alt Boyutlarından Alınan Puanlar

\begin{tabular}{|c|c|c|c|c|c|c|}
\hline ÇEBOE alt boyutları & Kitap okuma süresi & Sayı & Ortalama & SS & Test istatistiği & p-değeri \\
\hline \multirow{4}{*}{$\begin{array}{l}\text { Birlikte etkileşimli } \\
\text { okuma }\end{array}$} & 0 dakika & 22 & 2,98 & 0,85 & \multirow{4}{*}{$X^{2}=22,483$} & \multirow{4}{*}{$\begin{array}{l}<0,001 \\
\text { Fark: } \\
1-2,3,4\end{array}$} \\
\hline & 1-10 dakika & 102 & 3,36 & 0,49 & & \\
\hline & 11-20 dakika & 205 & 3,44 & 0,41 & & \\
\hline & 20 dakikadan fazla & 107 & 3,58 & 0,39 & & \\
\hline \multirow{4}{*}{$\begin{array}{l}\text { Birlikte okumaya } \\
\text { yönelik görüşler }\end{array}$} & 0 dakika & 22 & 2,74 & 0,59 & \multirow{4}{*}{$X^{2}=48,027$} & \multirow{4}{*}{$\begin{array}{l}<0,001 \\
\text { Fark: } \\
1-2-3,4\end{array}$} \\
\hline & 1-10 dakika & 102 & 3,21 & 0,45 & & \\
\hline & 11-20 dakika & 205 & 3,43 & 0,41 & & \\
\hline & 20 dakikadan fazla & 107 & 3,50 & 0,37 & & \\
\hline \multirow{4}{*}{$\begin{array}{l}\text { Okuryazarlığa model } \\
\text { olma }\end{array}$} & 0 dakika & 22 & 1,87 & 0,55 & \multirow{4}{*}{$X^{2}=35,306$} & \multirow{4}{*}{$\begin{array}{l}<0,001 \\
1-2-3,4\end{array}$} \\
\hline & 1-10 dakika & 102 & 2,31 & 0,60 & & \\
\hline & 11-20 dakika & 205 & 2,49 & 0,60 & & \\
\hline & 20 dakikadan fazla & 107 & 2,64 & 0,58 & & \\
\hline \multirow{4}{*}{$\begin{array}{l}\text { Okuryazarlığın } \\
\text { önemi }\end{array}$} & 0 dakika & 22 & 3,90 & 0,30 & \multirow{4}{*}{$X^{2}=0,710$} & \multirow{4}{*}{0,871} \\
\hline & 1-10 dakika & 102 & 3,91 & 0,19 & & \\
\hline & 11-20 dakika & 205 & 3,89 & 0,23 & & \\
\hline & 20 dakikadan fazla & 107 & 3,91 & 0,22 & & \\
\hline \multirow{2}{*}{$\begin{array}{l}\text { Okuryazarlık } \\
\text { öğretimi }\end{array}$} & 0 dakika & 22 & 2,26 & 0,74 & \multirow{2}{*}{$X^{2}=10,513$} & \multirow{2}{*}{$\begin{array}{l}<0,001 \\
\text { Fark: }\end{array}$} \\
\hline & 1-10 dakika & 102 & 2,61 & 0,68 & & \\
\hline
\end{tabular}




\begin{tabular}{lllll}
\hline 11-20 dakika & 205 & 2,52 & 0,76 & $1,3-4$ \\
20 dakikadan fazla & 107 & 2,72 & 0,77 & \\
\hline$X^{2}:$ Kruskat-Wanlis Ki-Kar
\end{tabular}

$\mathrm{X}^{2}$ : Kruskal-Wallis Ki-Kare değeri

Tablo 4'te görüldüğü gibi, annelerin çocuklarına kitap okumaya ayırdıkları zamana göre ÇEBOE alt boyutlarının 'Okuryazarlığın Önemi' boyutundan alınan puanlar arasında istatistiki açıdan anlamlı bir fark bulunamamıştır ( $p>0,05)$. 'Birlikte Etkileşimli Okuma' boyutunda çocuklarına kitap okumaya hiç zaman ayırmayan annelerin puanlarının diğerlerinden istatistiki olarak anlamlı derecede düşük olduğu görülmüştür $(\mathrm{p}<0,05)$. 'Birlikte Okumaya Yönelik Görüşler' ve ‘Okuryazarlığa Model Olma' boyutlarında çocuklarına kitap okumaya hiç zaman ayırmayan ve 1-10 dakika zaman ayıran annelerin puanlarının, 11-20 dakika ve 20 dakikadan fazla zaman ayıran annelerden anlamlı derecede düşük olduğu görülmüştür ( $\mathrm{p}<0,05$ ). 'Okuryazarlık Öğretimi' boyutunda ise, çocuklarına kitap okumaya 20 dakikadan fazla zaman ayıran annelerin puanları, hiç zaman ayırmayan ve 11-20 dakika zaman ayıran annelerin puanlarından anlamlı derecede yüksek bulunmuştur $(\mathrm{p}<0,05)$.

Annelerin evlerinde çocuklarına okuyabilecekleri kitap sayılarına göre ÇEBOE alt boyutlarından aldıkları puanlar Tablo 5'te verilmiştir.

Tablo V.

Annelerin Evlerinde Çocuklarına Okuyabilecekleri Kitap Sayısına Göre ÇEBOE Alt Boyutlarından Alınan Puanlar

\begin{tabular}{|c|c|c|c|c|c|c|}
\hline ÇEBOE alt boyutları & Kitap sayısı & Say1 & Ortalama & SS & Test istatistiği & p-değeri \\
\hline \multirow{4}{*}{$\begin{array}{l}\text { Birlikte etkileşimli } \\
\text { okuma }\end{array}$} & $0-2$ adet & 27 & 3,25 & 0,55 & \multirow{4}{*}{$X^{2}=5,402$} & \multirow{4}{*}{0,145} \\
\hline & 3-5 adet & 77 & 3,43 & 0,50 & & \\
\hline & $6-10$ adet & 112 & 3,40 & 0,46 & & \\
\hline & $11-20$ adet & 220 & 3,47 & 0,45 & & \\
\hline \multirow{4}{*}{$\begin{array}{l}\text { Birlikte okumaya } \\
\text { yönelik görüşler }\end{array}$} & $0-2$ adet & 27 & 2,87 & 0,52 & \multirow{4}{*}{$X^{2}=55,744$} & \multirow{4}{*}{$\begin{array}{c}<0,001 \\
\text { Fark } \\
1-2,3-4\end{array}$} \\
\hline & 3-5 adet & 77 & 3,19 & 0,45 & & \\
\hline & 6-10 adet & 112 & 3,34 & 0,39 & & \\
\hline & $11-20$ adet & 220 & 3,49 & 0,42 & & \\
\hline \multirow{4}{*}{$\begin{array}{l}\text { Okuryazarlığa model } \\
\text { olma }\end{array}$} & $0-2$ adet & 27 & 2,01 & 0,65 & \multirow{4}{*}{$X^{2}=35,639$} & \multirow{4}{*}{$\begin{array}{c}<0,001 \\
\text { Fark } \\
4-1,2,3\end{array}$} \\
\hline & 3-5 adet & 77 & 2,25 & 0,64 & & \\
\hline & 6-10 adet & 112 & 2,36 & 0,55 & & \\
\hline & $11-20$ adet & 220 & 2,62 & 0,59 & & \\
\hline \multirow{4}{*}{ Okuryazarlığın önemi } & $0-2$ adet & 27 & 3,90 & 0,25 & \multirow{4}{*}{$X^{2}=1,390$} & \multirow{4}{*}{0,708} \\
\hline & 3-5 adet & 77 & 3,93 & 0,19 & & \\
\hline & 6-10 adet & 112 & 3,89 & 0,25 & & \\
\hline & $11-20$ adet & 220 & 3,90 & 0,21 & & \\
\hline \multirow{4}{*}{ Okuryazarlık öğretimi } & $0-2$ adet & 27 & 2,46 & 0,62 & \multirow{4}{*}{$X^{2}=4,216$} & \multirow{4}{*}{0,239} \\
\hline & 3-5 adet & 77 & 2,74 & 0,67 & & \\
\hline & $6-10$ adet & 112 & 2,57 & 0,76 & & \\
\hline & $11-20$ adet & 220 & 2,54 & 0,78 & & \\
\hline
\end{tabular}

$X^{2}$ : Kruskal-Wallis Ki-Kare değeri

Tablo 5'te görüldüğü üzere annelerin evlerinde çocuklarına okuyabilecekleri kitap sayılarına göre ÇEBOE alt boyutlarının 'Birlikte Etkileşimli Okuma', 'Okuryazarlığın Önemi' ve 'Okuryazarlık Öğretimi' boyutlarından alınan puanlar arasında istatistiki açıdan anlamlı bir fark bulunamamıştır ( $p>0,05)$. 'Birlikte Okumaya Yönelik Görüşler' boyutunda 0-2 adet kitabı olan annelerin puanlarının 3-5 adet kitabı olan annelerden ve 6-10 adet kitabı olan annelerin puanlarının 11-20 adet kitabı olan annelerden anlamlı derecede düşük olduğu sonucuna ulaşılmıştır $(\mathrm{p}<0,05)$. 'Okuryazarlığa Model Olma' boyutunda ise 11-20 adet kitabı olan annelerin puanlarının diğerlerinden anlamlı derecede yüksek olduğu görülmüştür $(p<0,05)$.

Annelerin çocuklarına ilk kitaplarını aldıkları zamana göre ÇEBOE alt boyutlarından aldıkları puanlar Tablo 6'da verilmiştir. 
Tablo VI.

Annelerin Çocuklarına İlk Kitabı Aldıkları Zamana Göre ÇEBOE Alt Boyutlarından Alınan Puanlar

\begin{tabular}{|c|c|c|c|c|c|c|}
\hline ÇEBOE alt boyutları & $\begin{array}{l}\text { İlk kitap alınma } \\
\text { zamanı }\end{array}$ & Say1 & Ortalama & SS & Test istatistiği & p-değeri \\
\hline \multirow{6}{*}{$\begin{array}{l}\text { Birlikte etkileşimli } \\
\text { okuma }\end{array}$} & Doğduğunda & 36 & 3,64 & 0,30 & \multirow{6}{*}{$X^{2}=11,261$} & \multirow{6}{*}{0,056} \\
\hline & 1 yaşından sonra & 102 & 3,51 & 0,34 & & \\
\hline & 2 yaşından sonra & 84 & 3,36 & 0,48 & & \\
\hline & 3 yaşından sonra & 101 & 3,39 & 0,52 & & \\
\hline & 4 yaşından sonra & 51 & 3,40 & 0,38 & & \\
\hline & 5 yaşından sonra & 62 & 3,37 & 0,63 & & \\
\hline \multirow{6}{*}{$\begin{array}{l}\text { Birlikte okumaya } \\
\text { yönelik görüşler }\end{array}$} & Doğduğunda & 36 & 3,59 & 0,36 & \multirow{6}{*}{$X^{2}=55,337$} & \multirow{6}{*}{$\begin{array}{c}<0,001 \\
\text { Fark: } \\
1,2,3,4-5,6\end{array}$} \\
\hline & 1 yaşından sonra & 102 & 3,51 & 0,37 & & \\
\hline & 2 yaşından sonra & 84 & 3,36 & 0,43 & & \\
\hline & 3 yaşından sonra & 101 & 3,37 & 0,47 & & \\
\hline & 4 yaşından sonra & 51 & 3,27 & 0,45 & & \\
\hline & 5 yaşından sonra & 62 & 3,03 & 0,45 & & \\
\hline \multirow{6}{*}{$\begin{array}{l}\text { Okuryazarlığa model } \\
\text { olma }\end{array}$} & Doğduğunda & 36 & 2,79 & 0,48 & \multirow{6}{*}{$X^{2}=37,049$} & \multirow{6}{*}{$\begin{array}{c}<0,001 \\
\text { Fark: } \\
1,2-3,4,5,6\end{array}$} \\
\hline & 1 yaşından sonra & 102 & 2,64 & 0,54 & & \\
\hline & 2 yaşından sonra & 84 & 2,44 & 0,53 & & \\
\hline & 3 yaşından sonra & 101 & 2,38 & 0,68 & & \\
\hline & 4 yaşından sonra & 51 & 2,18 & 0,65 & & \\
\hline & 5 yaşından sonra & 62 & 2,30 & 0,62 & & \\
\hline \multirow{6}{*}{ Okuryazarlığın önemi } & Doğduğunda & 36 & 3,88 & 0,22 & \multirow{6}{*}{$X^{2}=6,384$} & \multirow{6}{*}{0,271} \\
\hline & 1 yaşından sonra & 102 & 3,89 & 0,22 & & \\
\hline & 2 yaşından sonra & 84 & 3,92 & 0,21 & & \\
\hline & 3 yaşından sonra & 101 & 3,88 & 0,23 & & \\
\hline & 4 yaşından sonra & 51 & 3,93 & 0,21 & & \\
\hline & 5 yaşından sonra & 62 & 3,92 & 0,22 & & \\
\hline \multirow{6}{*}{ Okuryazarlık öğretimi } & Doğduğunda & 36 & 2,53 & 0,77 & \multirow{6}{*}{$X^{2}=5,167$} & \multirow{6}{*}{0,396} \\
\hline & 1 yaşından sonra & 102 & 2,48 & 0,81 & & \\
\hline & 2 yaşından sonra & 84 & 2,57 & 0,75 & & \\
\hline & 3 yaşından sonra & 101 & 2,56 & 0,72 & & \\
\hline & 4 yaşından sonra & 51 & 2,73 & 0,73 & & \\
\hline & 5 yaşından sonra & 62 & 2,68 & 0,68 & & \\
\hline
\end{tabular}

$\mathrm{X}^{2}$ : Kruskal-Wallis Ki-Kare değeri

Tablo 6'da görüldüğü gibi, annelerin çocuklarına ilk kitaplarını aldıkları zamana göre ÇEBOE alt boyutlarının ‘Birlikte Etkileşimli Okuma', 'Okuryazarlığın Önemi’ ve ‘Okuryazarlık Öğretimi' boyutlarından alınan puanlar arasında istatistiki açıdan anlamlı bir fark bulunamamıştır ( $>00,05)$. 'Birlikte Okumaya Yönelik Görüşler' boyutunda çocuklarına doğduğunda, 1, 2 ve 3 yaşlarından sonra ilk kitaplarını alan annelerin puanları diğerlerinden istatistiksel olarak anlamlı derecede yüksek bulunmuştur $(p<0,05)$. 'Okuryazarlığa Model Olma' boyutunda çocuklarına doğduğunda ve 1 yaşından sonra kitap alan annelerin puanlarının diğerlerinden istatistiksel olarak anlamlı derecede yüksek olduğu görülmüştür $(p<0,05)$.

Annelerin Çocuklarıyla Birlikte Hikâye Okuma Davranışlarının, Aylık Gelir Düzeyi, Anne Yaşı ve Eğitim Düzeyi, Sahip Olunan Çocuk Sayısı, Çocuğun Yaşı ve Cinsiyetine Göre Değişip Değişmediğine İlişkin Bulgular

Annelerin ÇEBOE alt boyutlarından aldıkları puanların çocuğun cinsiyeti ve yaşına göre ve annelerin yaşı ve aylık gelir düzeylerine göre istatistiksel olarak anlamlı bir farklılık göstermediği tespit edilmiştir.

Annelerin eğitim düzeylerine göre ÇEBOE alt boyutlarından aldıkları puanlar Tablo 7' de verilmiştir. 
Tablo VII.

Anne Eğitim Düzeylerine Göre ÇEBOE Alt Boyutlarından Alınan Puanlar

\begin{tabular}{|c|c|c|c|c|c|c|}
\hline ÇEBOE alt boyutları & Eğitim durumu & Sayı & Ortalama & SS & Test istatistiği & p-değeri \\
\hline \multirow{5}{*}{$\begin{array}{l}\text { Birlikte etkileşimli } \\
\text { okuma }\end{array}$} & İlkokul & 83 & 3,45 & 0,47 & \multirow{5}{*}{$X^{2}=0,892$} & \multirow{5}{*}{0,926} \\
\hline & Ortaokul & 52 & 3,38 & 0,50 & & \\
\hline & Lise & 158 & 3,44 & 0,48 & & \\
\hline & Üniversite & 101 & 3,44 & 0,49 & & \\
\hline & Y. Lisans & 42 & 3,43 & 0,38 & & \\
\hline \multirow{5}{*}{$\begin{array}{l}\text { Birlikte okumaya } \\
\text { yönelik görüşler }\end{array}$} & İlkokul & 83 & 3,25 & 0,47 & \multirow{5}{*}{$X^{2}=11,022$} & \multirow{5}{*}{$\begin{array}{c}0,026 \\
\text { Fark: } \\
1-2,3,4,5\end{array}$} \\
\hline & Ortaokul & 52 & 3,28 & 0,40 & & \\
\hline & Lise & 158 & 3,40 & 0,43 & & \\
\hline & Üniversite & 101 & 3,38 & 0,51 & & \\
\hline & Y. Lisans & 42 & 3,45 & 0,40 & & \\
\hline \multirow{5}{*}{$\begin{array}{l}\text { Okuryazarlığa model } \\
\text { olma }\end{array}$} & İlkokul & 83 & 2,24 & 0,61 & \multirow{5}{*}{$X^{2}=29,781$} & \multirow{5}{*}{$\begin{array}{c}<0,001 \\
\text { Fark: } \\
1,2-3,4,5\end{array}$} \\
\hline & Ortaokul & 52 & 2,29 & 0,60 & & \\
\hline & Lise & 158 & 2,44 & 0,61 & & \\
\hline & Üniversite & 101 & 2,65 & 0,56 & & \\
\hline & Y. Lisans & 42 & 2,62 & 0,65 & & \\
\hline \multirow{5}{*}{ Okuryazarlığın önemi } & İlkokul & 83 & 3,96 & 0,14 & \multirow{5}{*}{$X^{2}=10,920$} & \multirow{5}{*}{$\begin{array}{c}0,027 \\
\text { Fark: } \\
1-2,3,4,5\end{array}$} \\
\hline & Ortaokul & 52 & 3,89 & 0,23 & & \\
\hline & Lise & 158 & 3,90 & 0,22 & & \\
\hline & Üniversite & 101 & 3,87 & 0,25 & & \\
\hline & Y. Lisans & 42 & 3,86 & 0,23 & & \\
\hline \multirow{5}{*}{ Okuryazarlık öğretimi } & İlkokul & 83 & 2,69 & 0,76 & \multirow{5}{*}{$X^{2}=5,634$} & \multirow{5}{*}{0,228} \\
\hline & Ortaokul & 52 & 2,66 & 0,72 & & \\
\hline & Lise & 158 & 2,58 & 0,69 & & \\
\hline & Üniversite & 101 & 2,50 & 0,86 & & \\
\hline & Y. Lisans & 42 & 2,42 & 0,69 & & \\
\hline
\end{tabular}

$X^{2}$ : Kruskal-Wallis Ki-Kare değeri

Tablo 7'de görüldüğü gibi, annelerin eğitim düzeylerine göre ÇEBOE alt boyutlarının 'Birlikte Etkileşimli Okuma' ve 'Okuryazarlık Öğretimi' boyutlarından alınan puanlar arasında istatistiki açıdan anlamlı bir fark bulunamamıştır ( $p>0,05)$. ‘Birlikte Okumaya Yönelik Görüşler' boyutunda ilkokul mezunu annelerin puanının diğer annelerin puanlarından istatistiksel olarak anlamlı derecede düşük olduğu; 'Okuryazarlığın Önemi' boyutunda ise ilkokul mezunu annelerin puanının diğer annelerin puanlarından istatistiksel olarak anlamlı derecede yüksek olduğu görülmüştür $(\mathrm{p}<0,05)$. ‘Okuryazarlığa Model Olma' boyutunda, ilkokul ve ortaokul mezunu annelerin puanlarının diğer eğitim kademelerinden mezun annelerin puanlarından istatistiksel olarak anlamlı derecede düşük olduğu görülmüştür $(p<0,05)$.

Annelerin sahip oldukları çocuk sayısına göre ÇEBOE alt boyutlarından aldıkları puanlar Tablo 8'de sunulmuştur.

Tablo VIII.

Annelerin Sahip Oldukları Çocuk Sayısına Göre ÇEBOE Alt Boyutlarından Alınan Puanlar

\begin{tabular}{|c|c|c|c|c|c|c|}
\hline ÇEBOE alt boyutları & Çocuk sayısı & Say1 & Ortalama & SS & Test istatistiği & p-değeri \\
\hline \multirow{3}{*}{$\begin{array}{l}\text { Birlikte etkileşimli } \\
\text { okuma }\end{array}$} & 1 çocuk & 99 & 3,42 & 0,52 & \multirow{3}{*}{$X^{2}=0,100$} & \multirow{3}{*}{0,951} \\
\hline & 2 çocuk & 234 & 3,45 & 0,44 & & \\
\hline & 3 ve üzeri & 103 & 3,41 & 0,50 & & \\
\hline \multirow{3}{*}{$\begin{array}{l}\text { Birlikte okumaya } \\
\text { yönelik görüşler }\end{array}$} & 1 çocuk & 99 & 3,38 & 0,52 & \multirow{3}{*}{$X^{2}=8,642$} & \multirow{3}{*}{$\begin{array}{c}0,013 \\
\text { Fark: } \\
3-1,2\end{array}$} \\
\hline & 2 çocuk & 234 & 3,40 & 0,42 & & \\
\hline & 3 ve üzeri & 103 & 3,25 & 0,44 & & \\
\hline
\end{tabular}




\begin{tabular}{|c|c|c|c|c|c|c|}
\hline \multirow{3}{*}{$\begin{array}{l}\text { Okuryazarlığa model } \\
\text { olma }\end{array}$} & 1 çocuk & 99 & 2,56 & 0,56 & \multirow{3}{*}{$X^{2}=13,158$} & \multirow{3}{*}{$\begin{array}{c}0,001 \\
\text { Fark: } \\
3-1,2\end{array}$} \\
\hline & 2 çocuk & 234 & 2,48 & 0,62 & & \\
\hline & 3 ve üzeri & 103 & 2,28 & 0,63 & & \\
\hline \multirow{3}{*}{ Okuryazarlığın önemi } & 1 çocuk & 99 & 3,89 & 0,23 & \multirow{3}{*}{$X^{2}=0,982$} & \multirow{3}{*}{0,612} \\
\hline & 2 çocuk & 234 & 3,90 & 0,21 & & \\
\hline & 3 ve üzeri & 103 & 3,91 & 0,23 & & \\
\hline \multirow{3}{*}{ Okuryazarlık öğretimi } & 1 çocuk & 99 & 2,66 & 0,75 & \multirow{3}{*}{$X^{2}=0,812$} & \multirow{3}{*}{0,666} \\
\hline & 2 çocuk & 234 & 2,55 & 0,73 & & \\
\hline & 3 ve üzeri & 103 & 2,54 & 0,80 & & \\
\hline
\end{tabular}

$X^{2}$ : Kruskal-Wallis Ki-Kare değeri

Tablo 8'de görüldügü üzere, annelerin sahip oldukları çocuk sayısına göre ÇEBOE alt boyutlarının 'Birlikte Etkileşimli Okuma', 'Okuryazarlığın Önemi' ve 'Okuryazarlık Öğretimi' boyutlarından alınan puanlar arasında istatistiki açıdan anlamlı bir fark bulunamamıştır ( $p>0,05)$. 'Birlikte Okumaya Yönelik Görüşler' ve 'Okuryazarlığa Model Olma' boyutlarında 3 ve üzeri sayıda çocukları olan annelerin puanlarının diğerlerinden istatistiksel olarak anlamlı derecede düşük olduğu görülmüştür $(p<0,05)$.

\section{Sonuç ve Tartışma}

Araştırmada annelerin evde çocuklarıyla birlikte hikâye kitabı okuma davranışları incelenmiştir. Araştırmaya katılan annelerin çoğunluğunun çocuklarına haftada 1-2 kez ya da hemen her gün hikâye kitabı okudukları ve kitap okumaya 11-20 dakika süre ayırdıkları görülmüştür. Ayrıca annelerin yarısından fazlasının evlerinde çocuklarına okuyabilecek 11-20 adet kitaba sahip oldukları ve çocuklarına genelde 1 ve 3 yaşlarından sonra ilk kitaplarını aldıkları tespit edilmiştir. Bu bulgular alanyazın ile paralellik göstermektedir. Işıkoğlu Erdoğan (2016) çalışmasında, ebeveynlerin \%36,9'unun haftada 1-2 kez, \%30,5'inin hemen her gün çocuklarıyla birlikte kitap okudukları, ancak \%8,4'ünün ise neredeyse hiç birlikte kitap okumadıkları; \%49'unun birlikte kitap okumaya 11-20 dakika süre ayırdıkları ve \%24,6'sının çocuklarına ilk kitabı 3 yaşından sonra aldıkları tespit edilmiştir. Benzer şekilde, Bracken ve Fischel (2008) çalışmasında da ebeveynlerin büyük bir kısmının her gün (\%54.08) ya da haftada 1-2 kez (\%34,76) birlikte okuma yaptıkları; kitap okumaya 11-20 dakika $(\% 25,32)$ ya da 20 dakikadan fazla $(\% 22,75)$ zaman ayırdıkları; evde çocuklarına okuyabilecekleri 1120 adet $(\% 26,61)$, 21-40 adet $(\% 21,46)$ ya da 40 'dan daha fazla sayıda $(\% 27,9)$ kitaba sahip oldukları görülmüştür. Duursma (2014) araştırmasında da ebeveynlerin büyük bir kısmının her gün (\%61) ya da haftada iki ya da üç kez (\% 21) birlikte okuma yaptıkları; birlikte okumaya yarısına yakınının (\%40) 5-10 dakika ve yine yarısına yakınının (\%40) 10-15 dakika süre ayırdıkları ve çocuk yaşı arttıkça okumaya ayrılan sürenin de arttığı görülmüştür. Raikes ve diğerleri, (2006) araştırmasında da çalışmaya katılan ebeveynlerin yaklaşık yarısının her gün (\%48,3), bir kısmının ise haftada birkaç kez (\%29) birlikte okuma yaptıkları tespit edilmiştir. Shahaeian ve diğerleri, (2018) çalışmasında 2-3 yaş aralığında çocukları olan ebeveynlerin yarısından fazlasının $(\% 61,6)$ her gün ve bir kısmının $(\% 21,1)$ ise haftada birkaç kez birlikte okuma yaptıkları görülmüştür. Ancak ülkemizde yapılan bir başka çalışmada, çocuğuna okul öncesi dönemde kitap okuyan annelerin oranının son derece düşük olduğu görülmüş ve okul öncesi dönemde ebeveynlerin çocuklarına kitap okuma konusunda yeterli duyarlılık göstermedikleri ileri sürülmüştür (Y1lmaz, 2004).

Araştırmaya katılan annelerin ÇEBOE ölçeğinden en yüksek ortalamayı sırasıyla 'Okuryazarlığın Önemi,' ‘Birlikte Etkileşimli Okuma' ve ‘ Birlikte Okumaya Yönelik Görüşler' boyutlarından, en düşük ortalamayı ise 'Okuryazarlığa Model Olma' ve 'Okuryazarlık Öğretimi' boyutlarından aldıkları tespit edilmiştir. Bu bulgular Işıkoğlu Erdoğan (2016) çalışmasındaki bulguları destekler niteliktedir. Söz konusu çalışmaya katılan ebeveynlerin ÇEBOE ölçeğinden en yüksek ortalamayı sırasıyla ‘Okuryazarlığın Önemi,' ‘Birlikte Etkileşimli Okuma' ve ' Birlikte Okumaya Yönelik Görüşler' boyutundan aldıkları, en düşük ortalamayı ise 'Okuryazarlığa Model Olma' ve 'Okuryazarlık Öğretimi' boyutlarından aldıkları tespit edilmiştir.

Araştırmaya katılan annelerin çocuklarına kitap okuma sıklıklarına göre 'Okuryazarlığın Önemi' ve 'Okuryazarlık Öğretimi' boyutlarından alınan puanlar arasında istatistiksel açıdan anlamlı bir fark olmadığı, 'Birlikte Etkileşimli Okuma,' 'Birlikte Okumaya Yönelik Görüşler' ve 'Okuryazarlığa Model Olma' 
boyutlarında ise daha sık okuyan anneler lehine bir farklılık olduğu görülmüştür. Bu bulgular Işıkoğlu Erdoğan (2016) çalışmasındaki bulgularla kısmen paralellik göstermektedir. Söz konusu çalışmada ebeveynlerin ÇEBOE ölçeğinin 'Birlikte Etkileşimli Okuma', 'Birlikte Okumaya Yönelik Görüşler', 'Okuryazarlığa Model Olma' alt boyut puanlarının yanı sıra 'Okuryazarlık Öğretimi' puanlarının da kitap okuma sıklığına göre farklılaştığı görülmüştür.

Araştırmaya katılan annelerin çocuklarına kitap okumaya ayırdıkları zamana göre ÇEBOE ölçeğinin 'Okuryazarlığın Önemi' boyutundan alınan puanlar arasında istatistiki açıdan anlamlı bir fark olmadığı, 'Birlikte Etkileşimli Okuma,' 'Birlikte Okumaya Yönelik Görüşler,' 'Okuryazarlığa Model Olma' ve 'Okuryazarlık Öğretimi' boyutlarında ise kitap okumaya daha uzun zaman ayıran anneler lehinde bir farklılık olduğu görülmüştür. Bulgular Işıkoğlu Erdoğan (2016) çalışmasındaki bulgularla paralellik göstermektedir. Söz konusu çalışmada ebeveynlerin ÇEBOE ölçeğinin ‘Birlikte Etkileşimli Okuma', ‘Birlikte Okumaya Yönelik Görüşler' ve 'Okuryazarlığa Model Olma' alt boyut puanlarının birlikte kitap okumaya ayrılan zamana göre farklılaştığı ve farklılığın kitap okumaya daha fazla zaman ayıran anneler lehine olduğu görülmüştür.

Annelerin çocuklarına kitap okuma sıklıkları ve kitap okumaya ayırdıkları zamana göre ÇEBOE alt boyutlarından aldıkları puanlar birlikte değerlendirildiğinde, kitap okuma sıklığı ve okumaya ayrılan zaman arttıkça annelerin birlikte okumaya yönelik görüşlerinin de arttığı dikkati çekmektedir. Bu bulgu birlikte okuma faaliyetlerinin ebeveynler üzerinde olumlu bir etkisi olduğunu göstermektedir. Nitekim Levy ve diğerleri (2018), çalı̧̧masında birlikte okuma faaliyetleri sonrasında daha önce okumaya ilgisi olmayan ebeveynlerin, okumaya ilgi duymaya başladıkları ve birlikte okumaya yönelik olumlu tutumlar geliştirdikleri görülmüştür. Bracken ve Fischel (2008) çalışmasında birlikte okuma sıklığı ve okumaya ayrılan zaman arasında istatistiksel olarak anlamlı ve olumlu yönde bir ilişki olduğu görülmüştür. Aynı çalışmada, birlikte okuma sıklığı ve okumaya ayrılan süre ile ilk kitap okuma yaşı, evdeki kitap sayısı ve çocuğun okumaya ilgisi ile okumaktan keyif alması arasında da istatistiksel olarak anlamlı ve olumlu yönde bir ilişki olduğu görülmüştür. Mevcut araştırma ve alanyazındaki bu bulgular, birlikte okumanın niceliksel özelliğini teşkil eden kitap okuma sıklığı ve okumaya ayrılan süre ile birlikte okumanın niteliksel özellikleri arasındaki etkileşime dikkat çekmektedir (Tercanlı Metin ve Gökçay, 2014).

Araştırmaya katılan annelerin evlerinde çocuklarına okuyabilecekleri kitap sayılarına göre ÇEBOE ölçeğinin 'Birlikte Etkileşimli Okuma', 'Okuryazarlığın Önemi' ve 'Okuryazarlık Öğretimi' boyutlarından alınan puanlar arasında istatistiki açıdan anlamlı bir fark olmadığı, 'Birlikte Okumaya Yönelik Görüşler' ve 'Okuryazarlığa Model Olma' boyutlarında ise daha çok sayıda kitabı olan anneler lehine bir farklılık olduğu görülmüştür. Evlerinde çocuklarına okuyabilecekleri kitap sayısı daha yüksek olan annelerin çocuklarıyla birlikte okumaya yönelik daha olumlu görüşleri olduğu ve okuryazarlığa daha fazla rol model oldukları bulgusu, ilgili alanyazın ile de örtüşmektedir. Zira daha önce de belirtildiği üzere, çocuklarda kitap okuma sevgisi ve alışkanlığı oluşturmada etkili unsurlardan birisi, çocukların erken yaşlardan itibaren nitelikli kitaplarla karşılaşmalarını sağlanmaktır (Aytaş, 2003; Sever, 2017; Temizyürek, 2003). Ne var ki, yapılan bir başka araştırmada çocukların yalnızca \%29,7'sinin evlerinde bir kitaplık bulunduğu tespit edilmiş ve bu durumun ebeveynlerin bilinçsizliğinin ve duyarsızlığının bir göstergesi olduğu ifade edilmiştir (Yılmaz, 2004). Evde çocukların okuyabilecekleri kitap sayısı, ev erken okuryazarlık ortamının özelliklerinden biri olup, Bracken ve Fischel (2008) araştırmasında evdeki kitap sayısı ile okuma sıklığı, ilk kitap okuma yaşı, okumaya ayrılan süre, çocuğun okumaya ilgisi ile okumaktan keyif alması arasında istatistiksel olarak anlamlı derecede ve olumlu yönde bir ilişki olduğu görülmüştür. Raikes ve diğerleri, (2006) araştırmasında da çocukların okuyabilecekleri kitap sayısı ile ebeveyn birlikte okuma sıklığı arasında bir paralellik olduğu tespit edilmiştir. Duursma (2014) araştırmasında çalışmaya katılan ebeveynlerin yarısına yakınının (\%48) evlerinde çocuklarına okuyabilecekleri 50 ya da daha fazla kitap olduğu ancak evdeki kitap sayısı ile birlikte okuma sıklığı arasında bir ilişki olmadığı görülmüştür.

Araştırmaya katılan annelerin çocuklarına ilk kitaplarını aldıkları zamana göre ÇEBOE ölçeğinin ‘Birlikte Etkileşimli Okuma', 'Okuryazarlığın Önemi' ve 'Okuryazarlık Öğretimi' boyutlarından alınan puanlar arasında istatistiki açıdan anlamlı bir fark olmadığı, ‘Birlikte Okumaya Yönelik Görüşler' ve ‘Okuryazarlığa Model Olma' boyutlarında çocuklarına daha erken yaşlarda kitap alan anneler lehinde bir farklılık olduğu 
görülmüştür. Kısaca, çocuklarına daha erken yaşlarda kitap alan annelerin çocuklarıyla birlikte okumaya yönelik daha olumlu görüşleri olduğu ve okuryazarlığa daha fazla rol model oldukları görülmüştür. Bıçakçı ve diğerleri (2017) çocuklarla kitap okunmaya olabildiğince küçük yaşlarda başlanılması gerektiğine dikkat çekmişlerdir. Bu nedenle, çocukların kitaplarla tanışmalarının tesadüflere bırakılmaması için ebeveynlerin anne-baba eğitimleri aracıllğılla bilgilendirilmesi ve böylece daha fazla çocuğun çok daha erken yaşlarda kitaplarla tanışmaları sağlanmalıdır.

Ayrıca not etmek gerekir ki, annelerin ÇEBOE ölçeğinin 'Okuryazarlığın önemi' alt boyutundan aldıkları puanların kitap okuma sıklığı, kitap okumaya ayrılan süre, evde çocuklarıyla okuyabilecekleri kitap sayısı ve çocuklarına ilk kitabı alma yaşına göre farklılık göstermediği görülmüştür. Bu durumda, annelerin aslında okuryazarlığın önemi boyutunda benzer görüşte oldukları yani okuryazarlığın önemine inandıkları ancak, bu hususta kendilerinin rolüne dair görüşlerinde ve birlikte okuma pratiklerinde farklılaştıkları söylenebilir. Benzer şekilde Husain ve diğerleri (2011) çalışmasında da annelerin okumanın önemine inandıkları ancak bunu destekleme konusunda yeterli özgüvene sahip olmadıkları görülmüştür. Birlikte okumaya yönelik ebeveyn özyeterlik algıları, birlikte okuma faaliyetlerinin niceliğini ve niteliğini etkileyen bir faktör olduğu için (Lin ve diğerleri, 2015; Kotaman, 2009) birlikte okumaya yönelik aile eğitim programlarında özellikle dikkate alınması gereken bir husustur.

Araştırmada annelerin ÇEBOE alt boyutlarından aldıkları puanların çocuğun cinsiyeti ve yaşına göre istatistiksel olarak anlamlı bir farklılık göstermediği tespit edilmiştir. Benzer şekilde Wu ve Honig, (2010) çalışmasında da ebeveynlerin birlikte okumaya yönelik görüşleri ile çocukların yaş ve cinsiyetleri arasında bir ilişki olmadığı görülmüştür. Ne var ki, çocuğun yaşının hem birlikte okuma faaliyetlerinin sıklığını ve niteliğini, hem de birlikte okumanın çocuğun gelişimi üzerine olan etkilerini şekillendiren bir özellik olduğunu gösteren pek çok araştırmaya da rastlanmıştır (Duursma, 2014; Gilkerson ve diğerleri, 2015; Marjanovič-Umek ve diğerleri, 2017; Raikes ve diğerleri, 2006; Tercanlı Metin ve Gökçay, 2014; Whitehurst ve diğerleri, 1988; Wu ve Honig, 2010). Örneğin, Bracken ve Fischel (2008) araştırmasında ebeveynin çocuğa ilk kitap okuma yaşı ile okuma sıklığı, okumaya ayrılan süre, evdeki kitap sayısı, çocuğun okumaya ilgisi ile okumaktan keyif alması arasında istatistiksel olarak anlamlı derecede ve olumlu yönde bir ilişki olduğu görülmüştür. Mevcut çalışmaya katılan annelerin çocuklarının 4-5 yaş aralığında oldukları dikkate alındığında, yaş aralığının annelerin birlikte okuma puanlarında anlamlı farklılığa yol açabilecek hetorejenlikte olmadığı düşünülebilir. Mevcut araştırmanın çocuğun cinsiyeti ile ilgili bulgusu da alanyazındaki bulgularla örtüşmemektedir. İlgili alanyazında çocuğun cinsiyetinin hem birlikte okuma faaliyetlerinin sıklık ve niteliğini, hem de birlikte okumanın çocuğun gelişimi üzerine olan etkilerini şekillendiren bir özellik olduğu belirtilmektedir (Gilkerson ve diğerleri, 2015; Raikes ve diğerleri, 2006; Tercanlı Metin ve Gökçay, 2014; Vandermaas-Peeler ve diğerleri, 2011). Ne var ki, alanyazındaki bulgular arasında da bir tutarlılık sağlanamamış, bazı çalışmalarda cinsiyetin farklılığa yol açtığı, bazılarında ise farklılı̆̆a yol açmadığı görülmüştür.

Araştırmaya katılan annelerin ÇEBOE alt boyutlarından aldıkları puanların annelerin yaşı ve aylık gelir düzeylerine göre istatistiksel olarak anlamlı bir farklılık göstermediği tespit edilmiştir. Bu bulgu da yine alanyazın (Duursma, 201; Raikes ve diğerleri, 2006; Tercanlı Metin ve Gökçay, 2014) ile örtüşmemektedir. Işıkoğlu Erdoğan (2016)'da ebeveynlerin 'Birlikte Etkileşimli Okuma', 'Birlikte Okumaya Yönelik Görüşler', ‘Okuryazarlığa Model Olma' ve 'Okuryazarlık Öğretimi' alt boyut puanları arasında gelir düzeyleri bakımından anlamlı farklılık olduğu görülmüştür. Gelir düzeyi yüksek ebeveynlerin daha fazla birlikte etkileşimli okuma yaptıkları, birlikte okumaya yönelik daha olumlu görüşe sahip oldukları ve okuryazarlığa daha fazla model oldukları ancak, çocuklarına daha az okuryazarlık öğretimi yaptıkları tespit edilmiştir. Bir başka araştırmada üst sosyoekonomik statüdeki ebeveynlerin tamamının, alt sosyoekonomik statüdeki ebeveynlerin ise \%68'inin çocuklarına evde kitap okudukları görülmüştür. Aynı çalışmada ayrıca alt sosyoekonomik statüdeki ebeveynlerden çocuğuna en çok kitap okuyan aile üyesinin anne olduğu, üst sosyoekonomik statüde ise anne ve babaların birlikte okuma faaliyetlerine benzer oranda katıldıkları görülmüştür (Özbek Ayaz, Güleç ve Şahin, 2017). Acat, Demiral ve Arın (2008) çalışmasında da ailelerin, çocuklarına kitap alma sıklığının ekonomik durumlarıyla doğru orantılı olduğu bulgusuna ulaşılmıştır. Aynı 
çalışmada yüksek sosyoekonomik bölgede yaşayan öğrencilerin kitap okuma sıklığının, diğer sosyoekonomik düzeye sahip bölgelerde yaşayan öğrencilere oranla daha yüksek olduğu da tespit edilmiştir. Cengiz (2013) annelerin birlikte kitap okuma bağlamında sergiledikleri iletişim biçemlerinin, anne eğitim ve aylık gelir düzeylerine göre önemli ölçüde farklılaştığını ortaya koymuştur. Bir başka çalışmada da ebeveynlerin ev ortamında yaptıkları okuma faaliyetlerinin düşük gelirli aileler ile yüksek gelire sahip aileler arasında gelir düzeyi yüksek olan ailelerin lehine farklılık gösterdiği görülmüştür (İflazoğlu Saban ve Altınkamış, 2014). Aylık gelir düzeyi ile ilgili bulgunun alanyazındaki bulgularla örtüşmediği dikkate alındığında, bu durumun çalışmaya katılan annelerin aylık gelir düzeyi dağılımından kaynaklanmış olabileceği düşünülebilir. Zira çalışmaya katılan annelerin yarısından fazlasının (\%55) aylık gelir düzeyinin 3001 TL ve üzeri olması nedeni ile aylık gelir düzeyi dağılımının annelerin ÇEBOE ölçeğinin alt boyut puanlarında farklılık yaratmaya yeter düzeyde heterojen olmadığı düşünülebilir.

Annelerin ÇEBOE ölçeğinin alt boyutlarından aldıkları puanların anne eğitim düzeyine göre farklılık gösterdiği tespit edilmiştir. Bu bulgu ilgili alanyazındaki bulgularla ile örtüşmektedir (Bracken ve Fischel, 2008; Duursma, 2014; Lyytinen ve diğerleri, 1998; Raikes ve diğerleri, 2006; Tercanlı Metin ve Gökçay, 2014; Wu ve Honig, 2010). Annelerin eğitim düzeylerine göre ÇEBOE alt boyutlarından aldıkları puanlara ilişkin bulgular Işıkoğlu Erdoğan (2016) bulguları kısmen örtüşmektedir. Söz konusu çalışmada ebeveynlerin 'Birlikte Etkileşimli Okuma', 'Birlikte Okumaya Yönelik Görüşler', 'Okuryazarlığa Model Olma' ve 'Okuryazarlık Öğretimi' alt boyut puanları arasında eğitim düzeyleri bakımından anlamlı farklılık olduğu ancak, 'Okuryazarlığın Önemi' alt boyut puanları arasında anne eğitim düzeyine göre anlamlı bir fark olmadığı görülmüştür. Yine bir başka araştırmada, öğrenim durumu lisans ve lisansüstü mezunu olan annelerin, çocuklarına ilk kitaplarını özel olarak aldıkları, bir yaşından önce onları kitapla tanıştırdıklarını ve kitap sevgisini kazandırmak için boş vakitlerinde onlara kitap okudukları belirlenmiştir (Ersoy ve Bayraktar, 2015). Mevcut çalışma ve alanyazındaki bu bulgular, eğitim seviyesi düşük ebeveynleri hedef alan anne-baba eğitim programlarında birlikte okuma konusunda bilgilendirmeye özellikle yer verilmesi gerekliliğini ortaya çıkartmaktadır.

Araştırmaya katılan annelerin ÇEBOE ölçeğinin alt boyutlarından aldıkları puanların sahip olunan çocuk sayısına göre farklılık gösterdiği tespit edilmiştir. Annelerin sahip oldukları çocuk sayısına göre ÇEBOE alt boyutlarından aldıkları puanlara ilişkin bu bulgular, İflazoğlu Saban ve Altınkamış (2014) bulguları ile de kısmen örtüşmektedir. Söz konusu çalışmada, aile okuma inanç puanlarının yordayıcıları arasında "tek çocuklu olma (\%1)" değişkeninin yer aldığı görülmüştür. Benzer şekilde Raikes ve diğerleri (2006) araştırmasında da annelerin ilk çocuklarına daha fazla kitap okudukları tespit edilmiştir.

\section{Sinırlılıklar ve Öneriler}

Araştırmanın örneklemi çocukları bir okul öncesi eğitim kurumuna devam eden annelerle sınırlıdır. Ebeveynlerin birlikte okuma faaliyetlerine yönelik ileride yürütülecek araştırmalarda babaların da örnekleme dâhil edilmesi önerilebilir. Zira ilgili alanyazına göre ebeveyn cinsiyeti, birlikte okuma faaliyetlerinin nicelik ve niteliğini etkileyen faktörlerden biridir.

Çalışmaya katılan annelerin çocuklarının 4-5 yaş grubunda olması araştırmanın bir diğer sınırlılığını teşkil etmektedir. İleride yürütülecek araştırmalarda örneklemin 0-6 yaş grubu çocuğu olan ebeveynleri kapsayacak şekilde genişletilmesi önerilebilir. Zira alanyazındaki bulgulara göre çocuk yaşı birlikte okumanın niceliğini ve niteliğini etkileyen bir faktördür. Ülkemizde 0-3 yaş grubunda okullaşma oranının 4-5 yaş grubuna göre daha düşük (Kazu ve Yılmaz, 2018) olduğu düşünüldüğünde, örneklemin bu şekilde genişletilmesi ayrıca, çocukları bir okul öncesi eğitim kurumuna devam etmeyen ebeveynlerin birlikte okumaya yönelik görüş ve uygulamaları hakkında da bilgi edilmesini sağlayacaktır.

Araştırma, annelerin bildirimine dayalı olarak veri toplamayı olanaklı kılan ÇEBOE ile sınırlıdır. ÇEBOE ebeveynlerin çocuklarıyla birlikte okuma davranışlarının niceliği ve ebeveynlerin birlikte okumaya yönelik görüşleri hakkında bilgi sağlamaktadır. Ne var ki, ebeveyn bildirimine dayalı bu bilgiler, birlikte okuma sürecinin gerçekte nasıl yürütüldüğünü, örneğin süreçte ebeveyn ile çocuk arasındaki etkileşimin sıklığını, etkileşimi kimin başlattığını, ne tür soruların yöneltildiğini vb. göstermemektedir. Bundan hareketle, evde 
birlikte okumaya yönelik ileride yürütülecek araştırmalarda gözleme dayalı verilerin de veri toplama sürecine dâhil edilmesi önerilebilir.

Araştırmada, annelerin evlerinde bulunan kitap sayıları arttıkça birlikte okumaya yönelik daha olumlu düşündükleri ve okuryazarlık açısından çocuklarına daha fazla rol model oldukları görülmüştür. İlgili alanyazınla da desteklenen bu bulgudan hareketle, annelerin çocuklarına okuyabilecekleri daha fazla kitaba erişim sağlayabilmeleri için kolay ulaşabilir yerlerde çocuk kütüphaneleri kurulabilir. Böylece anne ve çocukların, nitelikli çocuk edebiyatı ürünlerine üyelik sistemiyle ücretsiz bir şekilde erişmeleri ve aynı zamanda çocukların kütüphane kültürü kazanmaları sağlanabilir.

Araştırmada eğitim seviyesi yüksek annelerin çocuklarıyla daha sık birlikte okuma yaptıkları görülmüştür. İlgili alanyazınla da desteklenen bu bulgudan hareketle, anne baba eğitim programlarında özellikle de eğitim seviyesi düşük ebeveynlerin, birlikte okuma konusunda bilgilendirmesi önerilebilir. Yine bu kapsamda, Milli Eğitim Bakanlığı tarafından ülke genelindeki okulöncesi ve ilköğretim okulları bünyesinde "Ailemle Okuyorum" projesi geliştirilerek, birlikte okuma konusunda ebeveynlerde farkındalık kazandırılabilir.

Son olarak, araştırmada annelerin okuryazarlı̆̆ın önemine inandıkları ancak, bu hususta kendilerinin rolüne dair görüşlerinde ve birlikte okuma uygulamalarında farklılaştıkları görülmüştür. İlgili alanyazına göre ebeveynlerin birlikte okuma uygulamalarının nitelik ve niceliğini etkileyen faktörler arasında ebeveynlerin özyeterlik algıları yer almaktadır. Bundan hareketle, anne baba eğitim programlarında ebeveynlerin birlikte okuma özyeterlik algılarının desteklenmesi önerilebilir.

\section{Kaynaklar}

Acat, B., Demiral, H. ve Arın, A. (2008, Mayıs). Okuma alı̧kanlığı göstergelerine göre ilköğretim öğrencilerinin durumları. Türkçe Öğretimi Kongresi, Bahçeşehir Üniversitesi, İstanbul.

Akyol, T. (2012). Resimli çocuk kitaplarında yer alan değerlerin incelenmesi (Yayımlanmamış yüksek lisans tezi). Hacettepe Üniversitesi, Sosyal Bilimler Enstitüsü, Ankara.

Aram, D. ve Shapira, R. (2012). Parent-child shared book reading and children's language, literacy, and empathy development. Rivista Italiana di Educazione Familiare, 7(2), 55-65.

Aytaş, G. (2003). Okuma gelişiminde çocuk edebiyatının rolü. Türklük Bilimi Araştırmaları, 13, 155-160.

Baker, L., Scher D. ve Mackler, K. (1997). Home and family influences on motivations for reading. Educational Psychologist, 32, 69-82.

Baroody, A. E. ve Diamond, K. E. (2010). Links among home literacy environment, literacy interest, and emergent literacy skills in preschoolers at risk for reading difficulties. Topics in Early Childhood Special, 20, 1-10. doi:10.1177/0271121410392803.

Bıçakçı, M.Y., Er, S. ve Aral, N. (2017). Annelerin çocuklarına etkileşimli kitap okuma sürecine ilişkin görüşleri. Eğitim ve Bilim Dergisi, 42(191), 53-68. Doi:10.15390/EB.2017.7164

Bıçakçı, M.Y., Er, S. ve Aral, N. (2018). Etkileşimli öykü okuma sürecinin çocukların dil gelişimi üzerine etkisi. Kastamonu Ĕ̆itim Dergisi. 26(1), 201-208.

Bojczyk, K. E., Davis, A. E. ve Rana, V. (2016). Mother-child interaction quality in shared book reading: Relation to child vocabulary and readiness to read. Early Childhood Research Quarterly, 36(3), 404-414. doi: 10.1016/j.ecresq.2016.01.006.

Bracken, S. S. ve Fischel, J. E. (2008). Family reading behavior and early literacy skills in preschool children from low-income backgrounds. Early Education and Development, 19(1), 45-67.

Bus, A. G. ve van IJzendoorn, M.H. (1995). Mothers reading to their 3 year olds: The role of mother-child attachment security in becoming literate. Reading Research Quarterly, 30, 998- 1015. 
Bus, A.G., van IJzendoorn, M.H. ve Pellegrini, A.D. (1995). Joint book reading makes for success in learning to read: A meta-analysis on intergenerational transmission of literacy. Review of Educational Research, 65, 121.

Büyüköztürk, Ş. , Kılıç Çakmak, E. , Akgün, Ö.E. , Karadeniz, Ş. ve Demirel, F. (2014). Bilimsel araştırma yöntemleri. Ankara: Pegem Akademi.

Cengiz, Ö. (2013). Türk annelerin çocuklarına kitap okurken kullandıkları dil. Edebiyat Fakültesi Dergisi, 30(1), 97-114.

Çakmak Güleç, H. ve Geçgel, H. (2006). Çocuk edebiyatı. Ankara: Kök yayıncılık.

Çer, E. (2016). 0-6 yaş çocuk kitaplarında çocuk gerçekliği ve çocuğa görelik. Ankara: Eğiten Kitap.

Demir-Lira, E., Applebaum, L.R., Goldin-Meadow, S. ve Levine, S.C. (2018). Parents' early book reading to children: Relation to children's later language and literacy outcomes controlling for other parent language input. Developmental Science, 2019, e12764. doi:10.1111/desc.12764.

Deretarla Gül, E. (2015). Okul öncesi çocuklara okuma alışkanlığı kazandırma. M. Gönen (Ed.), Çocuk edebiyatı içinde (305-314). Ankara: Eğiten Kitap.

Dixon- Krauss, L., Januszka, C.M. ve Chae, C. (2010). Development of the dialogic reading inventory of parentchild book reading. Journal of Research in Childhood Education 24(3), 266-277. Erişim adresi: http://dx.doi.org/10.1080/02568543.2010.487412

Döl, A. (1999). 0-6 yaş çocuk kitapları resimlemeleri (Yayımlanmamış yüksek lisans tezi), Onsekiz Mart Üniversitesi, Sosyal Bilimler Enstitüsü, Çanakkale.

Dursunoğlu, H. (2013). Çocuk ve edebiyat. Ö. Yılar ve L. Turan (Ed.), Eğitim fakülteleri için çocuk edebiyatı (s. 27- 30) içinde. Ankara: Pegem Akademi.

Duursma, E. (2014). Parental bookreading practices among families in the Netherlands. Journal of Early Childhood Literacy, 14(4), 435-458.

Duursma, E. (2016). Who does the reading, who the talking? Low-income fathers and mothers in the US interacting with their young children around a picture book. First Language, 36(5), 465-484. doi: $10.1177 / 0142723716648849$.

Er, S. (2016). Okul öncesi dönemde anne babaların etkileşimli hikâye kitabı okumalarının önemi. Başkent Üniversitesi Ĕ̆itim Dergisi, 3(2), 156-160.

Ergül, C., Akoğlu, G., Sarıca, D., Tufan, M. ve Karaman, G. (2015). Ana sınıflarında gerçekleştirilen birlikte kitap okuma etkinliklerinin "etkileşimli kitap okuma" bağlamında incelenmesi. Mersin Üniversitesi Ĕ̆itim Fakültesi Dergisi, 11(3), 603-619. doi: 10.17860/efd.88429.

Ersoy, Ö. ve Bayraktar, V. (2015). Annelerin öğrenim durumlarına göre çocuklarını kitapla buluşturma konusundaki durumlarının incelenmesi (Çalışma Kapsamı: 57 İl). İlköğretim Online, 14(4), 1406-1415. doi: 10.17051/io.2015.42378

Gibbs, L. J. ve Earley, E. J. (1994). Using children's literature to develop core values. (Report No. ISBN-0-87367-362X). Bloomington, Ind.: Phi Delta Kappa Educational Foundation. (ERIC Document Reproduction Service No. ED 366992). 26 Şubat 2011 tarihinde https://files.eric.ed.gov/fulltext/ED366992.pdf adresinden erişildi.

Gilkerson, J., Richards, J. A. ve Topping, K. J. (2015). The impact of book reading in the early years on parentchild language interaction. Journal of Early Childhood Literacy, 17(1), 92-110. doi: 10.1177/1468798415608907.

Gonzalez, J. E., Taylor, A. B., Davis, M. J. ve Kim, M. (2013). Exploring the underlying factor structure of the Parent Reading Belief Inventory (PRBI): Some caveats. Early Education and Development, 24(2), 123-137.

Gönen, M. ve Arı, M. (1989). Anaokuluna giden dört-beş yaş çocuklarına resimli kitaplarla yapılan eğitimin dil gelişimine etkisinin incelenmesi. Ĕ̆itim ve Bilim, 13(72), 21-30. 
Gönen, M., Durmuşoğlu, M. ve Severcan, S. (2009). Examining the views of the preschool education teachers on the content, illustrations and physical characteristics of the picture story books used in education. Procedia Social and Behavioral Sciences, 1(1), 753-759.

Hindman, A. H. , Connor, C. M., Jewkes, A. M. ve Morrison, F. J. (2008). Untangling the effects of shared book reading: Multiple factors and their associations with preschool literacy outcomes. Early Childhood Research Quarterly, 23(3), 330-350.

Hindman, A. H. , Skibbe, L. E. ve Foster, T. D. (2014). Exploring the variety of parental talk during shared book reading and its contributions to preschool language and literacy: evidence from the Early Childhood Longitudinal Study-Birth Cohort. Reading And Writing, 27(2), 287-313.

Husain, F. M., Choo, J. C. S. ve Singh, M. K. M. (2011). Malaysian mothers' beliefs in developing emergent literacy through reading. Procedia-Social and Behavioral Sciences, 29, 846-855.

Hutton, J. S., Phelan, K., Horowitz-Kraus, T., Dudley, J., Altaye, M., DeWitt, T. ve Holland, S. K. (2017a). Story time turbocharger? Child engagement during shared reading and cerebellar activation and connectivity in preschool-age children listening to stories. PLOS ONE, 12(5), e0177398. doi: 10.1371/journal.pone.0177398.

Hutton, J. S., Phelan, K., Horowitz-Kraus, T., Dudley, J., Altaye, M., ... ve Holland, S. K. (2017b). Shared reading quality and brain activation during story listening in preschool-age children. Journal of Pediatrics, 191(December 2017), 204-212. doi: 10.1016/j.jpeds.2017.08.037.

Işıkoğlu Erdoğan, N. (2016). Erken çocukluk döneminde çocuk-ebeveyn birlikte okuma etkinliklerinin incelenmesi. Kastamonu Eğitim Dergisi, 24(3), 1071-1086.

İflazoğlu Saban, A. ve Altınkamış, N. F. (2014). Okul öncesi çağda çocuğu olan ebeveynlerin okuma inançlarının incelenmesi. International Journal of Human Sciences, 11(1), 317-337. doi: 10.14687/ijhs.v11i1.2761.

Karakuş, I. Ş. (2006). Çocuk edebiyatı ürünlerinin okuma gelişimine etkisi (Yayımlanmamış yüksek lisans tezi), Gazi Üniversitesi, Eğitim Bilimleri Enstitüsü, Ankara.

Kazu, İ.Y. ve Yılmaz, M. (2018). Ükemizdeki okul öncesi eğitimin bazı veriler açısından OECD ve AB üyesi ülkeleri ile karşılaştırılması. Turkish Journal of Educational Studies, 5(2), 64-75. doi: 10.33907/turkjes.404695

Kıbrıs, İ. (2000). Uygulamalı çocuk edebiyatı. Ankara: Eylül Yayınevi.

Kim, J.E. ve Anderson, J. (2008). Mother-child shared reading with print and digital texts. Journal of Early Childhood Literacy, 8(2), 213-245.

Kolaç, E. , Demir, T. ve Karadağ, R. (2012). Öğretmen adaylarının dil eğitiminde çocuk edebiyatı metinlerinin kullanımına yönelik görüşleri. Türkiye Sosyal Araştırmalar Dergisi, 161, 195-213.

Kotaman, H. (2007). Turkish parents' dialogical storybook reading experiences: A phenomenological study. Journal of Instructional Psychology, 34(4), 200-206.

Kotaman, H. (2008) Impacts of dialogical storybook reading on young children's reading attitudes and vocabulary development. Reading Improvement, 45(2), 55-61.

Kotaman, H. (2009). Ana-babaların hikâye kitabı okumaya ilişkin özyeterlilik ölçeği. Türk Ĕ̆itim Bilimleri Dergisi, 7(4), 767-780.

Kraayenoord, C.E.V. ve Paris S.G. (1996). Story construction from a picture book: an assessment activity for young learners. Early Chilhood Research Quarterly, 11, 41-61.

Krcmar, M. ve Cingel, D.P. (2014). Parent-child joint reading in traditional and electronic formats. Media Psychology, 17(3), 262-281, doi: 10.1080/15213269.2013.840243.

Kurt, B. (2008). Çocuk edebiyatı ürünlerinin temel dil becerisi olarak dinlemenin gelişimine etkisi (Yayımlanmamış 
yüksek lisans tezi), Gazi Üniversitesi Eğitim Bilimleri Enstitüsü, Ankara.

Levin, I. ve Aram, D. (2012). Mother-child joint writing and storybook reading and their effects on kindergartners' literacy: An intervention study. Reading and Writing, 25(1), 217-249. doi:10.1007/s11145010-9254-y.

Levy, R. Hall, M. ve Preece, J. (2018). Examining the links between parents' relationships with reading and shared reading with their pre-school children. International Journal of Educational Psychology, 7(2), 123-150. doi:10.17583/ijep.2018.3480.

Lin, J., Stephanie, M.R. ve Sabrina, K. (2015). Maternal reading self-efficacy associated with perceived barriers to reading. Child Development Research, 2015, 1-7. doi: 10.1155/2015/218984.

Lyytinen, P., Laakso, M.L. ve Poikkeus, A. M. (1998). Parental contribution to child's early language and interest in books. European Journal of Psychology of Education, 13(3), 297-308. doi: 10.1007/BF03172946.

Marjanovič-Umek, L., Hacin, K. ve Fekonja, U. (2017). The quality of mother-child shared reading: Its relations to child's storytelling and home literacy environment. Early Child Development and Care. doi: 10.1080/03004430.2017.1369975.

Morrow, L. ve Gambrell, L. (2005). Using children's literature in preschool: Comprehending and enjoying books. Newark, DE: International Reading Association.

Oktay, A. (2000). Yaşamın sihirli yılları: Okul öncesi dönem. İstanbul: Epsilon.

Özbek Ayaz, C., Güleç, H. ve Şahin, Ç. (2017). Ailelerin, çocuklarıyla birlikte gerçekleştirdikleri okuma aktivitelerinin düzeyini belirleme. Ahi Evran Üniversitesi Kırşehir Eğitim Fakültesi Dergisi,18(1), 1-19.

Öztürk, G., Hill, S. ve Yates, G. (2016). Family context and five-year-old children's attitudes toward literacy when they are learning to read. Reading Psychology, 37(3), 487-509. doi: 10.1080/02702711.2015.1066909.

Raikes, H., Pan, B.A., Luze, G., Tamis-LeMonda, C.S., Brooks-Gunn, J., ... ve Rodriguez, E.T. (2006). Motherchild bookreading in low-income families: Correlates and outcomes during the first three years of life. Child Development, 77(4), 924-953.

Revelle, G. ve Bowman, J. (2017, June). Parent-child dialogue with ebooks. In, Proceedings of the 10th International Conference on Interaction Design and Children (pp. 346-351). New York: ACM. Erişim adresi: https://doi.org/10.1145/3078072.3079753

Saracho, O.N. (2017). Parents' shared storybook reading - learning to read. Early Child Development and Care. 187(3-4), 554-567. doi: 10.1080/03004430.2016.1261514.

Sever, S. (2017). Çocuk ve edebiyat. Ankara: Tudem.

Shahaeian, A., Wang, C., Tucker-Drob, E., Geiger, V., Bus, A.G. ve Harrison, L.J. (2018). Early shared reading, socioeconomic status, and children's cognitive and school competencies: Six years of longitudinal evidence. Scientific Studies of Reading, 22(6), 485-502. doi: 10.1080/10888438.2018.1482901.

Sınar, A. (2006). Türkiye' de çocuk edebiyatı çalışmaları. Türkiye Araştırmaları Literatür Dergisi, 4(7), 175-225.

Şimşek, T. ve Yakar, Y. M. (2014). Çocuk ve edebiyat. T. Şimşek (Ed.), Kuramdan uygulamaya çocuk edebiyatı (s. 13- 44) içinde. Ankara: Grafiker.

Şirin, M. R. (2000). 99 soruda çocuk edebiyatı. İstanbul: Çocuk Vakfı.

Şirin, M. R. (2007). Çocuk edebiyatına eleştirel bir bakış. Ankara: Kök Yayıncılık.

Temizyürek, F. (2003). Türkçe öğretiminde çocuk edebiyatının önemi. Türklük Bilimi Araştırmaları, 2003(13), 161-167.

Tercanlı Metin, G. ve Gökçay, G. (2014). Bebeklik ve erken çocukluk döneminde kitap okuma: Çocuk sağlığı izlemlerinde etkili bir gelişim önerisi. Çocuk Dergisi, 14(3), 89-94. 
Tipton, L. A. (2014). The parent's role: Shared book reading and the child with asd (Yayımlanmamış doktora tezi). University of California, Riverside.

Tür, G. ve Turla, A. (2005). Okul öncesinde çocuk, edebiyat ve kitap. İstanbul: Yapa.

Vandermaas-Peeler, M., Sassine, B., Price, C. ve Brilhart, C. (2011). Mothers 'and fathers' guidance behaviours during storybook reading. Journal of Early Childhood Literacy, 12(4), 415-442.

Veziroğlu, M. (2009). Resimli çocuk kitaplarının M.E.B. okul öncesi eğitim programındaki kazanımlara uygunluğunun incelenmesi (Yayımlanmamış yüksek lisans tezi). Hacettepe Üniversitesi Sosyal Bilimler Enstitüsü, Ankara.

Whitehurst, G. J., Falco, F. L., Lonigan, C. J., Fischel, J. E., DeBaryshe, B. D., ...ve Caulfield, M. (1988). Accelerating language development through picture book reading. Developmental Psychology, 24(4), 552559. doi:10.1037/0012-1649.24.4.552

Whitehurst, G. T. ve Lonigan, C. J. (1998). Child development and emergent literacy. Child Development, 69(3), 848-872.

Wu, C.C. ve Honig, A.S. (2010). Taiwanese mothers' beliefs about reading aloud with preschoolers: findings from the parent reading belief inventory. Early Child Development and Care, 180(5), 647-669, doi: 10.1080/03004430802221449.

Yalçın, A. ve Aytaş, G. (2014). Çocuk edebiyatı. Ankara: Akçağ.

Yavuzer, H. (1995). Çocuk psikolojisi. İstanbul: Remzi Kitabevi.

Yılmaz, B. (2004). Öğrencilerin okuma ve kütüphane kullanma alışkanlıklarında ebeveynlerin duyarlılığı. Bilgi Dünyası, 5(2), 115-136.

Yurtseven, L. (2011). Annelerin çocuklarına hikâye okumasının çocukların sosyal beceri gelişimine etkisinin incelenmesi (Yayımlanmamış yüksek lisans tezi), İnönü Üniversitesi, Eğitim Bilimleri Enstitüsü, Malatya. 


\section{EXTENDED ABSTRACT}

\section{Introduction}

The preschool period, in which children's cognitive, social, and emotional foundations are laid, is of critical importance for gaining the love and habit of reading. And for the development of the love and habit of reading during preschool years, adults' involvement in reading activity with children is important (Bus et al., 1995; Çakmak Gulec and Gergel, 2006; Isikoglu Erdogan, 2016; Gambrell, 2005; Tipton, 2014; Whitehurst and Lonigan, 1998; Yurtseven, 2011). Shared reading, also known as interactive reading, refers to the interaction between the child and the adult while the adult is reading a book to the child (Gonzalez, Taylor, Davis and Kim, 2013; Hindman, Skibbe and Foster, 2014; Işıkoğlu Erdoğan, 2016). The aim of the study is to examine mother-child shared reading behaviors.

\section{Method}

The research is designed in descriptive survey model. The sample of the study was determined by cluster sampling method and is composed of 436 mothers whose children attend to kindergarten. The data were gathered through the Child-Parent Shared Reading Activities Scale (ÇEBOE), which was developed by Işıkoğlu Erdoğan (2016). There are 6 questions about parent and child demographics in the scale, 7 questions about reading, and 31 items in 4-point Likert type to measure reading behaviors. The scale consists of five subdimensions: Interactive Reading, Opinions of Shared Reading, Modeling Literacy, Importance of Literacy, and Literacy Teaching. Data were analyzed using Student's t test, Mann-Whitney U test, One-Way Variance Analysis (ANOVA) and Kruskal-Wallis $\mathrm{H}$ test in addition to descriptive statistics.

\section{Results}

The research findings indicate that mothers always participated in interactive reading $(3,43)$, opinions of shared reading $(3,36)$, and the importance of literacy $(3,90)$; they occasionally participated in the dimension of literacy teaching $(2,58)$, and rarely participated in the dimension of modeling literacy $(2,45)$. In terms of reading habits, it was found that the majority of the mothers participating in the study read a story book 1-2 times a week $(\% 37,2)$ or almost every day $(\% 24,8)$ to their children; they spent $11-20$ minutes $(\% 47)$ or more than 20 minutes $(\% 24,5)$ for reading books; they had $11-20$ books $(\% 50,5)$ or $6-10$ books $(\% 25,7)$ that they could read to their children at home and that they bought the first book for their children when the child was at 1 year of age $(\% 23,4)$ or at 3 years of age $(\% 23,2)$. In addition, it was found that mothers' shared reading behaviors were differed in accordance to mothers' level of education and the number of children they had; the frequency in which they read to their children, the time they spend in reading to their children, the number of books at home that they could read to their children, and the age of the child when mothers bought them their first book. The results indicate that the mothers who read to their children more frequently and spend more time for reading to their children, who had more books at home that they could read to their children, who bought the first book to their children when the child was at younger ages participated in shared reading activities more than the other mothers. Finally, the results indicate that mothers with higher level of education and those who have only one child had more positive opinions of shared reading than the other mothers. However, no statistically significant differences were found in mothers' shared reading behaviors by child's age and gender; by mothers' age and income.

\section{Conclusion}

One of the main findings of this study is that majority of the mothers always participated interactive reading, opinions of shared reading, and the importance of literacy while they occasionally participated in literacy teaching and rarely participated in modeling literacy. This finding indicates high awareness among mothers about the importance of early literacy activities at home in children's lives. However, this finding also indicates that children lack role models at home in terms of literacy related activities which is in support of the finding in Işıkoğlu Erdoğan (2016) study where majority of the parents rarely become a role model for reading though they "strongly stated that reading is very important for their children, they want them love reading, introduce books them at early ages" (p. 1086). 
There is a vast amount of literature indicating the relationship between family income and home literacy environment and support (e.g., Acat, Demiral and Arın, 2008; Cengiz, 2013; Işıkoğlu Erdoğan, 2016; İflazoğlu Saban and Altınkamış, 2014; Özbek Ayaz, Güleç and Şahin, 2017). However, no relationships no differences were found between mothers' shared reading behaviors by income in the present study. One possible explanation for this contradiction could be that the sample of the present study was not heterogeneous enough in terms of mothers' income to display the differences in their shared reading behaviors since more than half of them (\%55) had income 3001TL or higher.

Finally the finding that mothers' shared reading behaviors differed by their level of education points out the need to support mothers with low education level with parent education programs regarding shared reading so that they could provide their children with a more supportive home literacy environment. 